\title{
Sustainable River Basin Management Planning: A Holistic Approach
}

\author{
Sonali Swetapadma and C.S.P. Ojha \\ Department of Civil Engineering, IIT Roorkee, Roorkee - 247667, Uttarakhand, India \\ E-mail: sonaliswetapadma1992@gmail.com;cspojha@gmail.com
}

\begin{abstract}
Water is the most vital element to life on earth, which can be a limited resource in an expanding global economy and population. The river water, a major source of surface water, finds multiple uses in irrigation, navigation, hydropower generation, flood management etc., thereby increasing the degree of complexity regarding its distribution among the users. The planning and management of river basin have gradually evolved over time with the change in water demand and also the river condition. Since last few decades, it has started moving towards a more scientific and technical approach consisting of integrated practices and management. India, being the second most populous nation of the world, its limited water resources is increasingly constrained by growing demand for irrigation and industrialization, which in turn has raised the level of pollution in many holly rivers along with interstate water disputes. To deal with all these conflicts, the river basin planning requires a sustainable holistic modeling of the entire basin for the socio-economic development of the country. This paper recounts the evolution of river basin planning stages with a special focus on holistic modeling along with some major issues rising in the water stressed-country like India.
\end{abstract}

Keywords: River basin; interstate water disputes; holistic modelling; socio-economic.

\section{INTRODUCTION}

\section{River Basin and Its Importance}

A river is a major source of fresh water naturally flowing from an origin towards the mouth located in an ocean or sea, according to the topography of its course. In ancient times, many civilizations were evolved near the bank of a river; later which found multiple uses of this river water, such as household and farm distributions, industrial and commercial uses, a source of energy in many hydropower generation units and a habitat for animals also. During its flow, a river and its tributaries drained into a land surface known as river basin, where water gets collected from the sources and discharged at a common outlet point as shown in Fig. 1. This river basin functions as a hydrological unit, basically used for water resource development and management, because it mainly focuses on the movement and effective distribution of water within upstream and downstream locations.

First Invited talk of 'Prof. Subhash Chander Memorial Lecture Series' organized by The Society of Earth Scientists at Lucknow on 23 October 2017. 


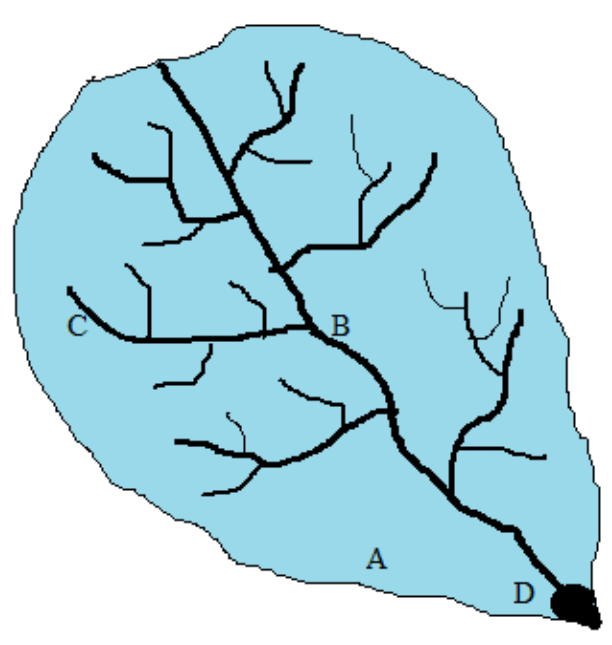

(a)

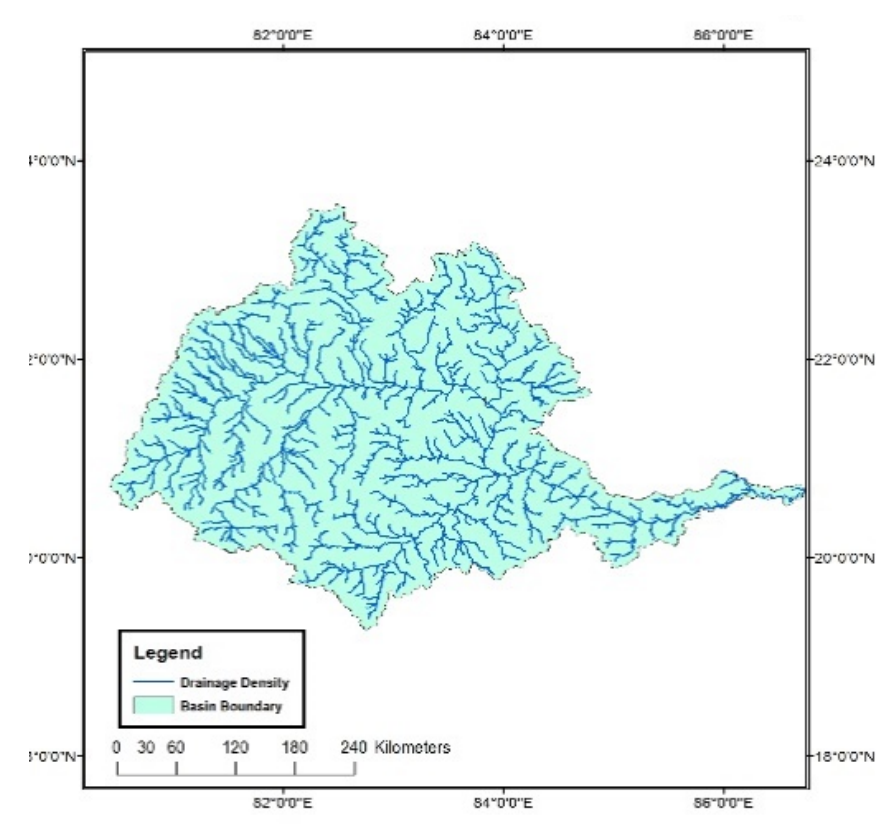

(b)

Fig.1: (a) The major features of a river basin (A: Basin, B: Confluence, C: Tributaries and D: Mouth); (b) Map of Mahanadi river basin, India.

So river basins are bio-geophysical units with a high degree of functional integrity and are relatively homogeneous systems, even when upper, middle and lower sections of a river have different conditions and human activities (Barrow, 1998). These basins play a vital role in hydrology with a prerequisite of proper planning and management due to growing demand of water. The flow of sediment from higher to lower elevation along a river course try to change the channel form in the basin, thereby making it a matter of concern in fluvial geomorphology also. The river flow also affects the ecological processes in a basin, as it carries many minerals, sediments, nutrients, pollutants from agricultural and industrial sources towards its journey to the basin outlet. So the concept of river basin has gained much more importance with its gradual evolution over time.

The very initial concept of both rivers and the hydrological cycle was first developed by Chinese in early third century BC (Guowei, 2001). One of the initial development in the field of river basins was noticed in Sri Lanka, which involved reservoirs and diversion of rivers through canals and interbasin transfers (Molle, 2009). Even though the concept of river basin was there at an early stage, but at that time the major focus was only on the flow of a river and its utilization in several fields. The importance of river basin was gradually increased due to growing demand of water within the basin, interbasin connections, diversion for irrigation and navigation purposes etc. Growth in natural science and technology in the middle of $19^{\text {th }}$ century increased the demand of water resources for various purposes like irrigation, navigation, power generation and also the evolving industrialization needs. Because of this rising demand, water became a major natural resource and its planning and management turned out to be a regional issue on the national level in many countries all around the world. Later in the $19^{\text {th }}$ century, some countries faced the pollution problem due to exponentially growing population and many political issues related to the demand of water for navigation and irrigation purposes. So during that stage, river basin planning and management were partially suppressed by these new issues raised in the field of water resources such as the construction 
of irrigational structures, flood management, reservoir planning etc. Later in the beginning of 20th century, planning of river basin gained much more importance as a necessity for the complete exploitation of a river's natural capability.

\section{Classification of River Basins}

Except for some cold and arid areas, most of the world's land surface is divisible into river basins (Barrow, 1998). Based upon Indian experience, (Chitale, 1992)classified the river basins into three major types according to their sizes, such as large basin having a catchment area greater than $20000 \mathrm{~km}^{2}$, medium basin within $2000 \mathrm{~km}^{2}$ to $20000 \mathrm{~km}^{2}$ and small basin with an area less than $2000 \mathrm{~km}^{2}$. For a very large basin, the entire basin can further be classified into upper, middle and lower sub-basins based on geological and climatological characteristics. In India, various organizations like India Water Resource Information System (IWRIS), Central Water Commission (CWC), Central Ground Water Board (CGWB), National Commission for Integrated Water Resource Development Plan (NCIWRDP) and also some agricultural groups have classified the entire country into various river basins according to their requirement as presented below in Fig.2.

The entire country has been classified into 25 major river basins by IWRIS using SRTM $90 \mathrm{~m}$ resolution satellite dataset, which is further divided into 103 sub-basins. There are 22 major river basins according to CWC classification, with specific ID and catchment area as shown in

Fig.3. NCIWRDP and CGWB have classified the entire country into 24 and 34 subbasins respectively. However, AISLUS categorized the total water resource of India into six major regions, which comprises 35 river basins, 112 catchments along with 500 subcatchments.

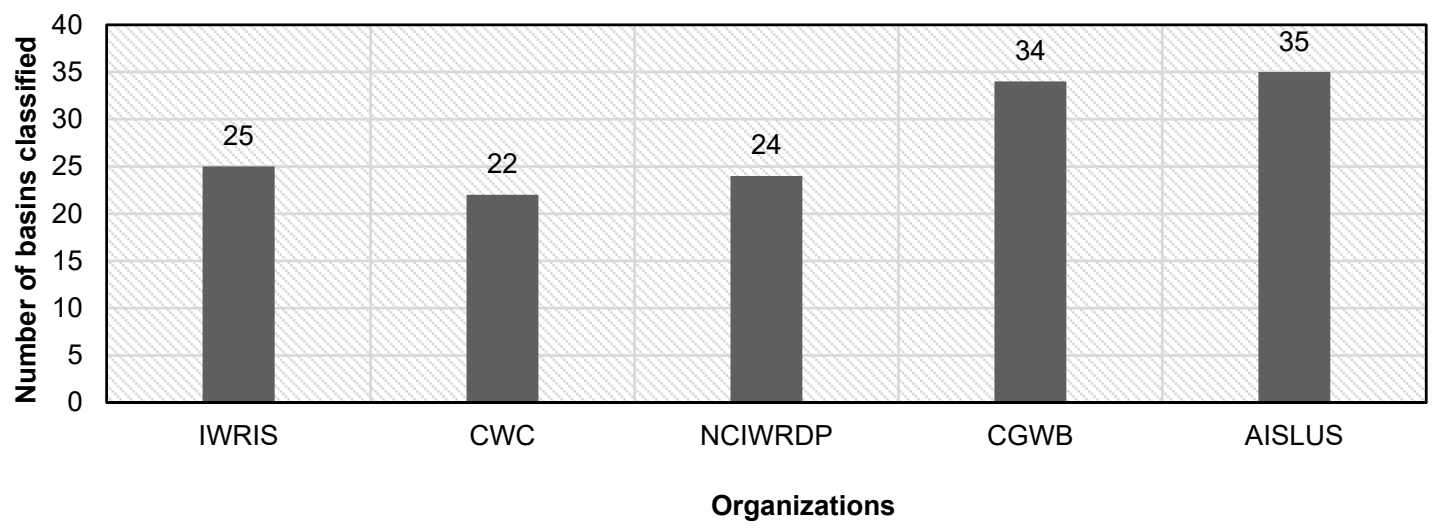

Fig.2: River basin classification in India according to various government organizations. 


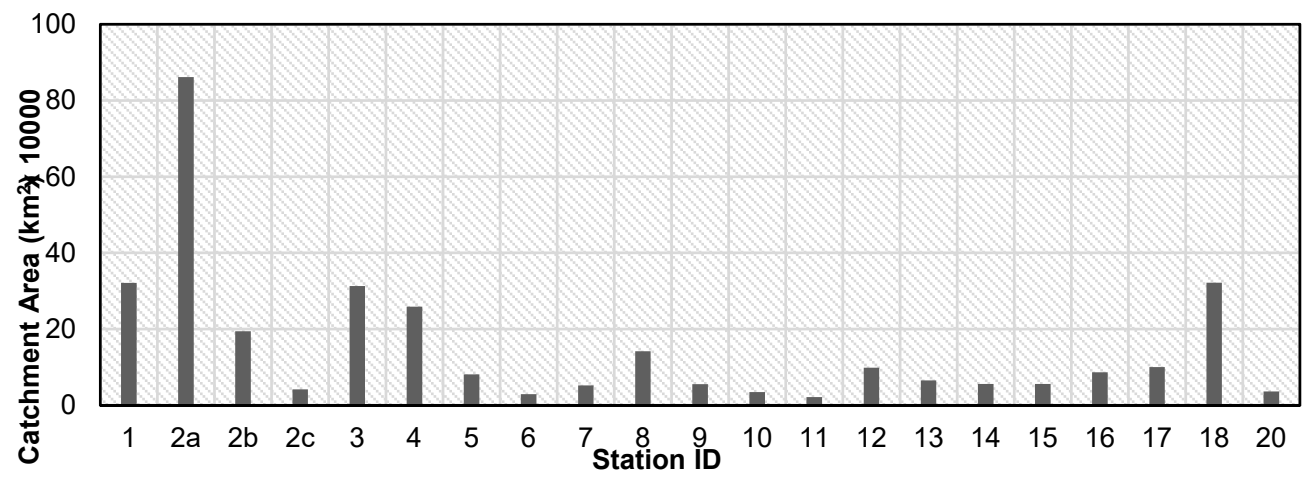

Fig.3: Catchment area of various river basins classified by Central Water Commission (CWC), India.

Some of the researchers have made an attempt to reclassify the Indian River basins by applying various techniques. One of those recent work was carried by Basu and Srinivas (2016), who applied Entropy Based Clustering Technique (EBCT) for regional flood frequency analysis, which yielded seven new homogeneous regions in four major basins such as Mahanadi, Godavari, Krishna, and Cauvery (Fig. 4).

They found these regions to be more effective than existing six regions of Indian government organizations obtained by applying $\mathrm{K}-$ means clustering and ROI (Region of Influence) approach. The EBCT classified regions were found to have better regional homogeneity leading to more precise flood quantile estimations.

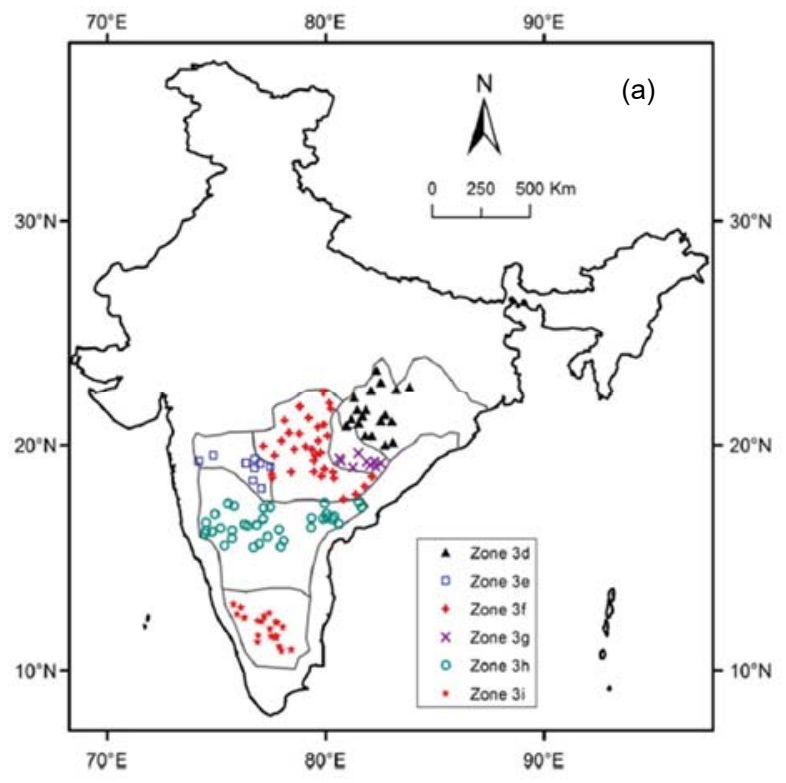

(a)

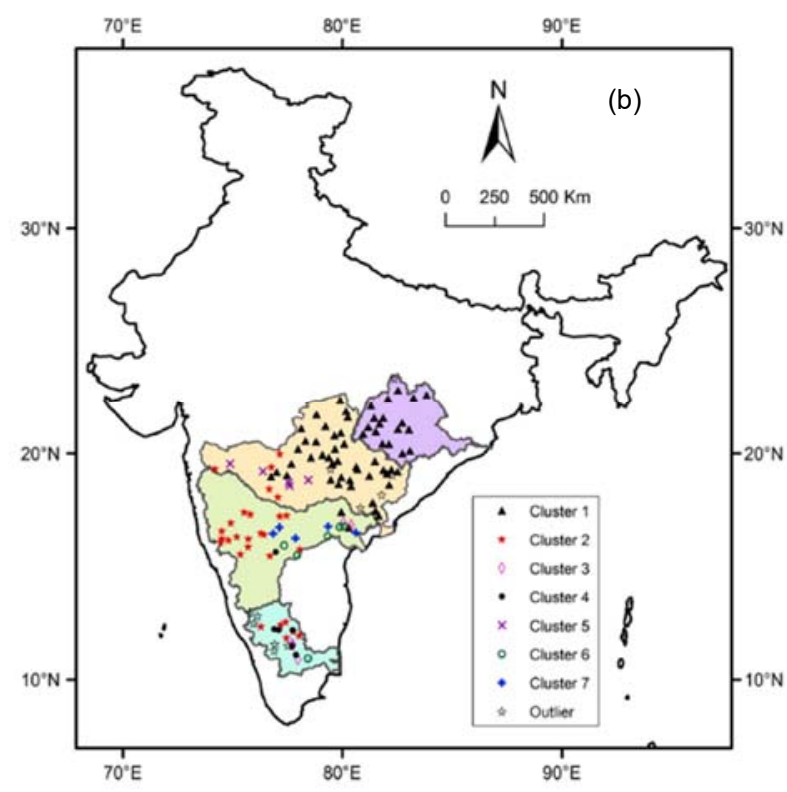

(b)

Fig.4: Hydrometeorologically homogeneous regions; (a) given by CWC for flood quantile estimation and (b) obtained by applying EBCT (Basu and Srinivas, 2016). 


\section{River Basin Development, Planning, and Management (RBDPM)}

Planning and management of river water at the basin level have been carried out since many decades; while it's moving towards more scientific and engineering based approach with its gradual evolution over time. River basin planning mainly deals with numerous prolific and economic ways, by which the limited water resources of a river can be efficiently managed to achieve all possible requirements for the socio-economic development of a country.

Initially, to utilize water distribution among the users planning was made at a local level, which gradually started moving towards a more technical approach such as the construction of hydraulic structures for optimum and regularized distribution of water resource. As a result of which, several political, social, economic and ecological issues raised in many countries all around the world. In the present scenario, requirement of more river water than its natural capability is prompting over-extraction, pollution, habitat destruction etc., which is mainly due to lack of proper planning and management at the basin level. So to account for all these conflicts, in the last few years, the river basin planning and management (RBDPM) is heading towards a sustainable holistic modeling of water resources with more emphasis on effective integrated practices. It primarily concentrates on modeling the entire river basin by the complete analysis of all possible situations and prioritizing the conflicts in order to achieve the set objectives with the help of some governmental bodies. In brief, the major aim of basin planning has been shifted from 'how to utilize more water' to 'optimum utilization of existing water resources for maximum benefit'.

However, this strategic planning has introduced a few complexity and uncertainty in the process, which is mainly caused by climate change and change in socio-economic conditions. This complex component includes variation in water availability with respect to time and space, climate unpredictability, shortage of data for analysis, interbasin links etc. The change in climate causes irregular pattern in rainfall, evaporation, and runoff, thereby affecting the available water resources and its planning process, whereas the existing climate models can't fully ensure the planners to make precise decisions with this spatial and temporal variability. All these add a significant future change with a very high degree of uncertainty to the planning process.

\section{General Layout of any RBDPM}

The main aim of strategic basin planning is to choose the best suitable plan among a number of choices in order to achieve the required goals, with the involvement of stakeholders and other governmental institutions. The basic three components of any RBDPM are planning, management, and dispute resolution, operating both at national and international level. Various approaches have been developed by many countries, most of which mainly includes the following process.

- A thorough understanding of the entire system:

- Analyze basic physical, geological and hydrological characteristics of the basin 
- Interactions between various ecological, social, environmental and institutional systems of the basin

- Estimate natural capability of the river

- Predict possible future demands

- Prioritizing issues to be solved:

- Analyze trade-off between various issues to be resolved

- Prioritize the issues based on social and environmental impacts, technical and economic feasibilities

- Choice of best possible solution among a number of choices;

- Look for the solutions satisfying the socio-economic needs along with political requirements

- The best solution should be an adaptive one ready to take any complexity and uncertainty involved in the system

- Preparation of thematic plans;

- Supporting plans for solving individual water management problems like water quality, irrigation, navigation, flood management etc.

- Thematic plans should properly coordinate between the river basin system and administrative officials

- Involvement of stakeholders and other institutions;

- To put the plan into action, involve various government bodies and stakeholders

- Final Selection of basin plan and implementation;

- Choice of a master plan satisfying all local needs of the basin along with socioeconomic issues, with a greater flexibility to adopt any uncertainties

\section{Classification of RBDPM}

RBDPM can be broadly categorized into following six classes, such as single purpose, dual purpose, multi-purpose, comprehensive, integrated and holistic (Barrow, 1998). Earlier river basin planning was mainly one directional, solving a single purpose at one time like irrigation, navigation, flood control etc. When planners and designers were required to satisfy demand from more people, like distributing water from a basin to fulfill both irrigation and flood control requirements, there came the dual purpose RBDPM. However, with an increase in demand for water resources, various conflicts regarding the distribution of water gradually came into the picture, which made the planners think about multi-purpose RBDPM. However, at that time, available water resource was simply distributed among various users without deciding the optimum benefits. A planned, complex, continuous and interdisciplinary process which is controlled on a system analysis basis is known as Comprehensive RBDPM (Molle, 2009). The major emphasis was optimizing the use of both land and water resources with less concern about social development. An integrated approach is a stronger version of comprehensive RBDPM with more focus on solving social issues related to human safety. It has been applied in many countries for integrating water resource planning, management, and development for optimal socio-economic benefits and found to be successful both at national and regional scale. Then comes the holistic approach for river basin planning, which involves a thorough understanding of the entire system or basin along with all the uncertainties involved as a prerequisite of conflict resolution. It differs from other approaches in terms of the complete study of the basin instead of part by part analysis, using effective strategized planning. This holistic modeling takes care of all the political, social, economic and ecological issues in an efficient way. This is represented graphically in the following Fig.5. 


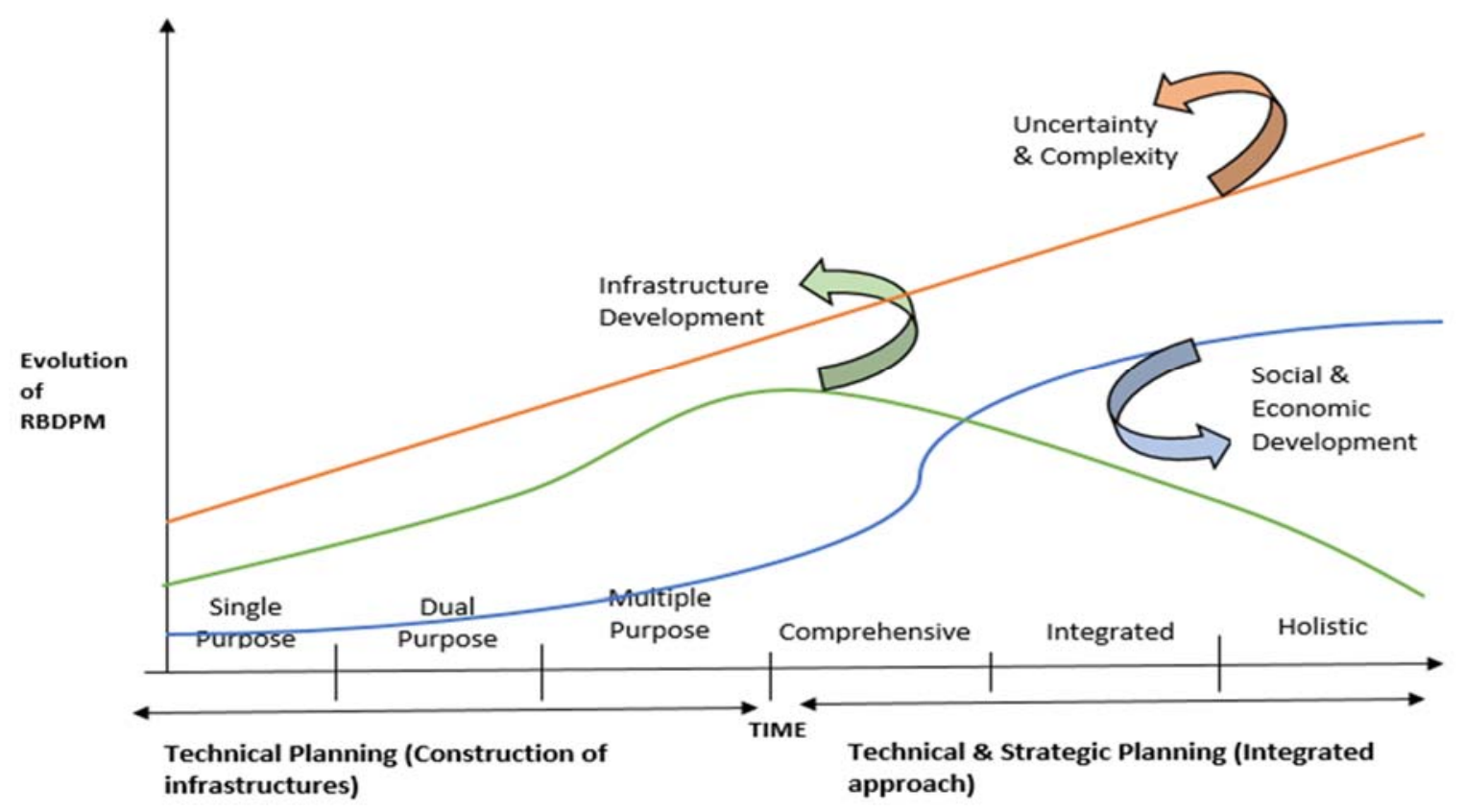

Fig.5: Evolution of various RBDPM over time.

\section{SUSTAINABLE RIVER BASIN PLANNING AND MANAGEMENT}

A global need for sustainable water resource management has been evolved in the last two decades due to rapid change in climate and water demand (Pahl-wostl et al., 2013, Girard etal., 2015). Sustainable river basin management is an integrated approach having the major focus on both social and economic development, with a prerequisite of a comprehensive understanding of the entire river basin and related uncertainties involved, with respect to time and space. The two major components (i.e. social and economic issues) can be combined either by 'Compartment modeling' or 'Holistic modeling' (Braat and Lierop, 1987). The compartment modeling treats both the components as separate ones leading to their individual solution. However, the holistic approach to sustainable river basin management uses both social and economic models as a single entity with a unified perspective towards various interactions within the ecological system. The later one can be solved by combined simulation and optimization techniques, while the holistic approach requires the solution of the entire system as a whole, mainly by implementing Stochastic Dynamic Programming (SDP), linear programming or quadratic programming etc. (Cai et al., 2006). A holistic approach mainly concentrates on the involvement of stakeholders in the basin management program. Some remarkable work in this field include, Mccarl et al., 1999; Cai et al., 2003; Cai et al., 2002; Jenkins et al., 2004; Booker et al., 2005; Schoups et al., 2006; Farolfi et al., 2010; Beall et al., 2011; Mirchi et al., 2012; Levin et al., 2013; Kotir et al., 2017; Kotir et al., 2016 etc. So the Holistic Water Resources Economic Model (HWEM) is an effective tool to handle sustainable 
river basin management program mainly in water scared regions, where there are a lot of social, environmental and political issues arising due to growing demand for river water.

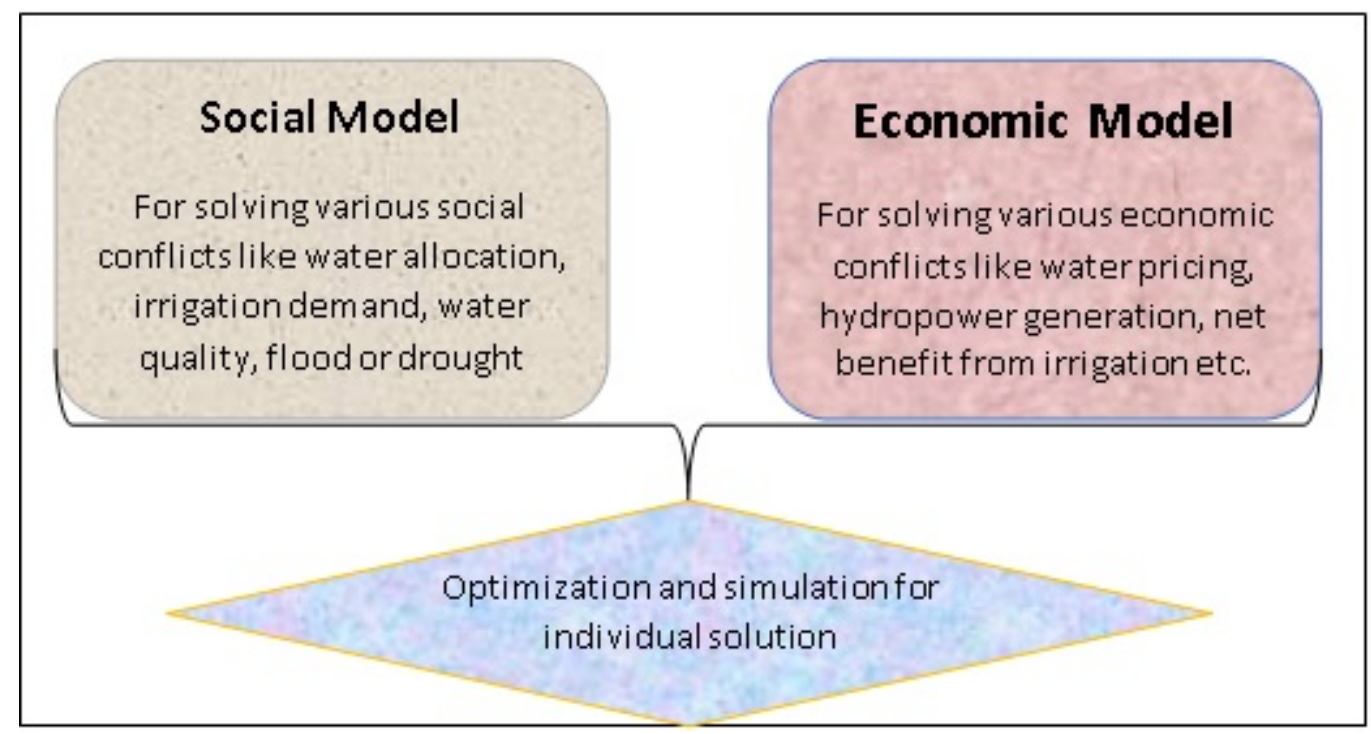

Fig.6: Principal Components of a Compartment Model.

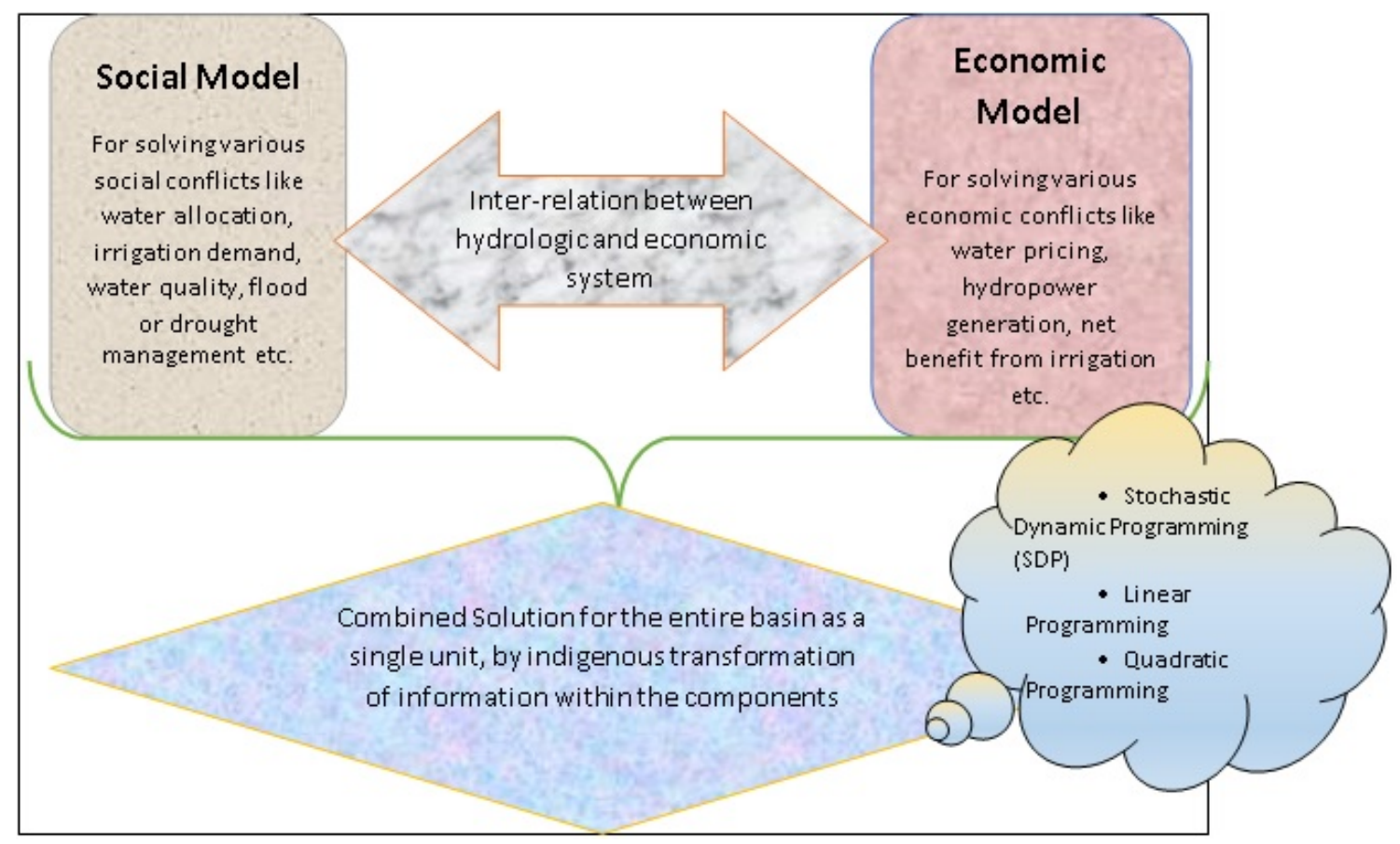

Fig.7: Principal components of a holistic model. 


\section{Basic Elements of a Holistic Model}

Holistic model is a dynamic model of any river basin extending from the root zone of crops in the field to the river system, with the aim of optimizing the benefits obtained from various demands like irrigation, water supply in municipal and industrial (M\&l) areas, hydropower generation etc. Depending upon the degree of complexity and uncertainty involved at a particular basin level, this model will have different components governed by four major relationships such as, hydrologic, economic, agronomical and institutional. (Cai et al., 2006) identified the following elements of any holistic model of this type while developing a HWEM for the Maipo River Basin.

- Consistent accounting for water storage and flows, diversions at each location and sector, actual consumptive use of water by location and sector, and return flows to the river system.

- Integrated accounting of the flow and generation of pollutants through the river basin.

- Representation of the demand for water and economic benefits from water use at each demand site and the effect of water and soil pollutants on the economic benefits from water use by location and sector.

- Consideration of both instream and off-stream water uses.

- Incorporation of institutional rules and policies that govern water allocation for each sector at a location, including priority allocation water rights, water pricing etc.

\section{Implementation of Holistic Model}

Before developing any model for a river basin, a thorough understanding of the entire river network along with the inter-relationship between all the involved processes is required. Initially, a river basin model should be developed preferably as a node-link network representing the course of the river, various storage works along the path, M\&l sites, an abstraction for irrigation and hydropower generation etc. A schematic basin network is shown in Fig.8, where nodes represent some important physical entities along the river course such as point of confluence or location where water gets diverted towards any municipal, industrial or agricultural area, which is connected by links. All these components of the basin model are interlinked by various hydrological, agronomical and economic relationships. The hydrological process includes the flow of water from river source or reservoir to the crop field for agricultural uses, to the M\&I sites, flow for hydropower generation, recharge of groundwater, return flow from all these sites, precipitation and potential evapotranspiration in the field etc. as shown inFig.9. Various mathematical and empirical relationships along with rainfall-runoff models can be applied to account for these processes. Major agronomic components include crop yield, irrigation technology, salinity in the field etc. Mathematical expressions involving partial derivatives are used for the analysis of these components. The economic part comprises the net benefits obtained from agricultural, M\&I and power generation demands in terms of various benefit-cost ratio. Models are developed for water trading at each demand site for clear representation and analysis of water pricing and other policies. Finally, the developed model should follow the governing institutional rules and regulations because the involvement of 
stakeholders is necessary for the better implementation of the model both at national and international level.

However, execution of these holistic models for sustainable river basin management is not that straightforward by simply combining social and economic components because of the following complexities and uncertainties involved.

\section{- The requirement of a large amount of data:}

For an integrated holistic model of a river basin a large amount of database including hydrological, meteorological, economic, agricultural, water demands in various sectors, per capita availability etc. is required. So collection and handling of these data become very difficult as the volume increases. The method of collecting these data is also different such as experimental, field observed, empirical or statistical and the spatial and temporal scales also vary. The scale between the hydrological and economic components should have an adequate match for effective transfer of information between them. As these uncertainties involved in the process makes data management very difficult, so the model output should be checked for any kind of sensitivity.

\section{- Institutional involvement:}

Models developed for any basin should be well designed according to the rules and regulation of the organizations involved in that basin area. So here come the various challenges involved while following the basic rules along with the involvement of stakeholders at different levels. These rules can be implemented into the model as constraints based on which all the decisions are made to have optimum socio-economic benefits from the basin.

\section{- Difficulty in the calibration of model:}

It is very difficult to calibrate a holistic model used for sustainable river basin planning and management because a large number of parameters are involved in the process and also they are interdependent. Calibration is important while developing an unbiased positive model, where the developed model output is calibrated by using a recent year data under the existing management practices.

After addressing all the complexities involved in the model, the model is solved by different efficient mathematical approaches. As most of the process is non-linear in nature and also the model size becomes very large while considering the entire basin, it is effective to solve these optimization models by 'piece by piece' approach with subsets of variables and constraints which union is the entire model. Most of the non-linear optimization models are solved by this piece by piece approach by disintegrating the entire model into various submodels. So with a proper selection of spatial and temporal scales between hydrologic and economic components and accounting all the uncertainties, holistic approach can be an effective strategy for sustainable river basin planning and management. The gradual evolution of information and technology system has a great potential for the implementation of such large complex model over a very large spatial area. 
Earth Science India eISSN: $0974-8350$

Vol. 10 (IV), October, 2017, pp. 126 - 152

http://www.earthscienceindia.info/

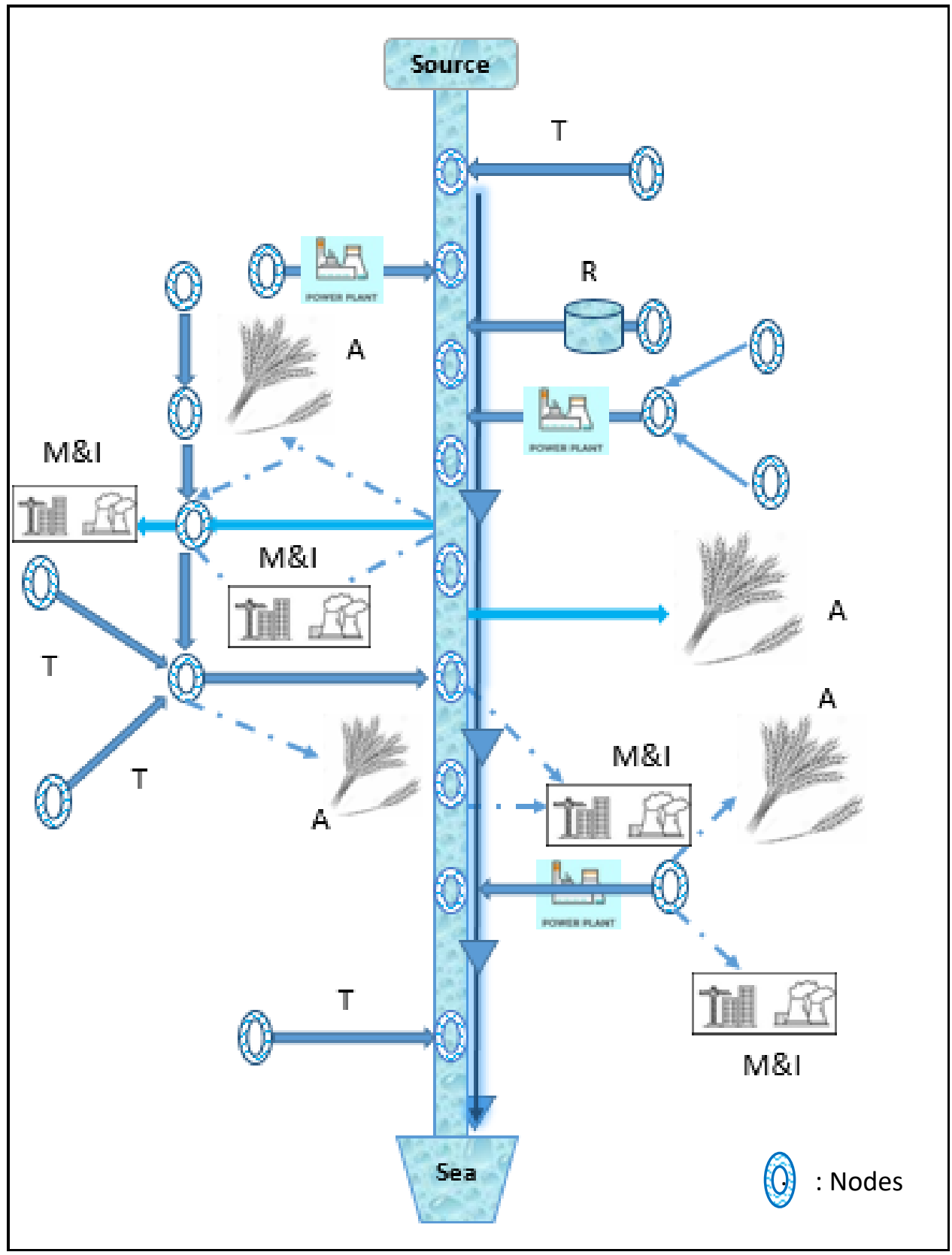

Fig.8: Schematic diagram of a river network (R: Reservoir, T: Tributaries, A: Agricultural Land, M\&I: Municipal and Industrial Uses) 


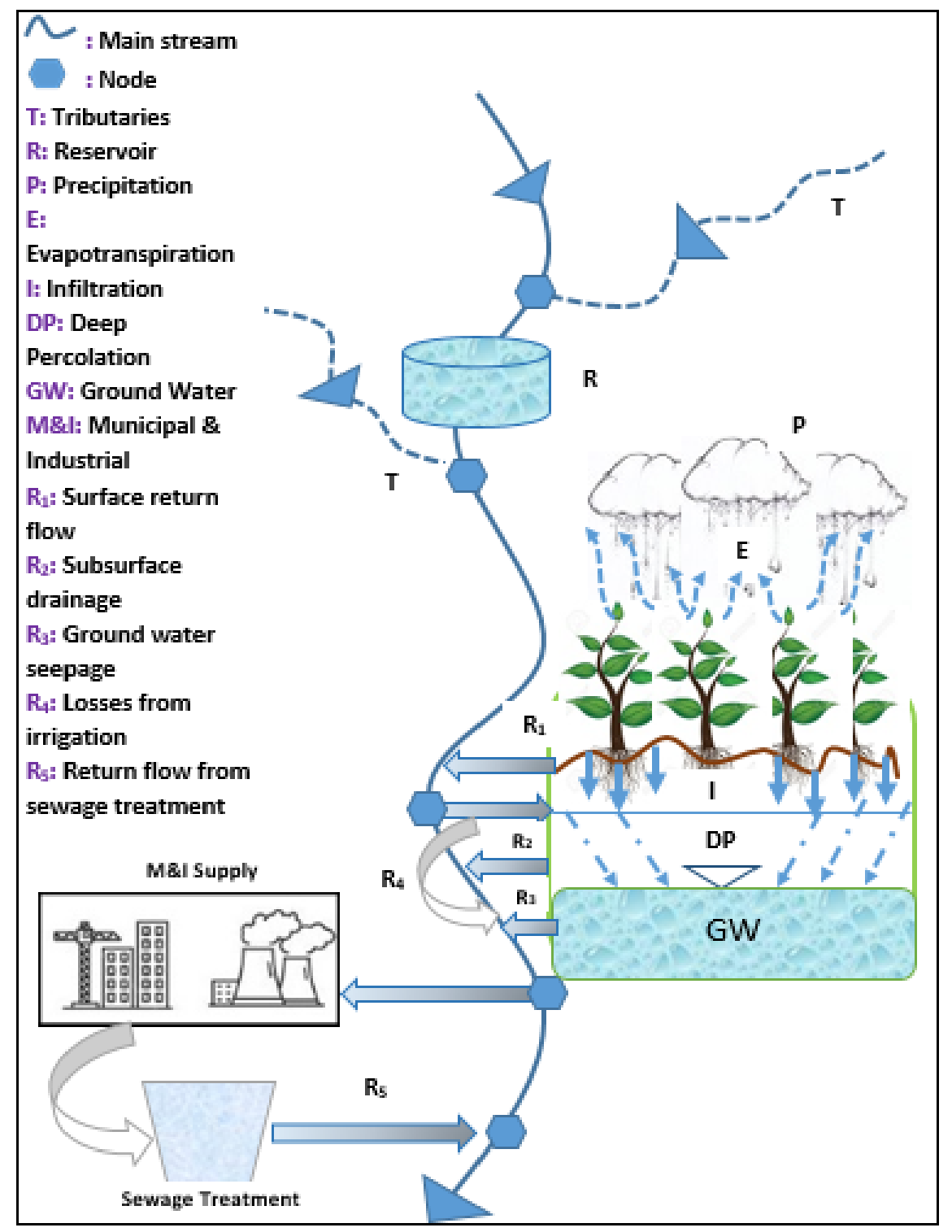

Fig.9: Hydrologic process involved in a standard holistic model used for RBDPM.

\section{RBDPM: A BRIEF GLANCE AT INDIAN SCENARIO}

\section{Water Resources in India}

Precipitation (including rainfall and snowfall) being the major source of water in India, accounts for an annual volume of $4000 \mathrm{~km}^{3}$; out of which $1869 \mathrm{~km}^{3}$ of water is accessible as average annual potential flow in rivers that occurs as natural runoff considering both surface water and groundwater. From the available water resources, only $1123 \mathrm{~km}^{3}$ is exploitable which consists of $690 \mathrm{~km}^{3}$ of surface water and the rest $433 \mathrm{~km}^{3}$ as the groundwater resource, because of the large variability in climate and catchment topography with respect to time and space. Out of these utilizable surface water, $370 \mathrm{~km}^{3}$ of water is obtainable from the non- 
Earth Science India

classified river basins in India. The live storage capacity of all the non-classified basins is $253.4 \mathrm{~km}^{3}$ and $51 \mathrm{~km}^{3}$ is under construction. A pie chart showing more detailed classification of available water resources in India is given below in Fig. 10.

As estimated on 1st March 2011, the national per capita annual water availability is $1545 \mathrm{~m}^{3}$ (Integrated Hydrological Data Book, 2017). However, the average availability of water is also different for different river basins depending on their location, climate conditions, population growth and some other factors. Brahmaputra and Barak basin with $7.6 \%$ of the geophysical area and $5.2 \%$ of the population of all the basins in the country, has $31 \%$ of annual water resources i.e. $14057 \mathrm{~m}^{3}$. The per capita water availability at different years is given by Central Water Commission (CWC) in Integrated Hydrological Data book (IHD, 2017) which is presented in Fig.11. As clear from the chart, the per capita water availability in India is decreasing at a faster rate, such as in 2010 the per capita availability was $1608 \mathrm{~m}^{3}$ against $5200 \mathrm{~m}^{3}$ in 1951. As an international standard, per capita availability below $1700 \mathrm{~m}^{3}$ is considered as 'water stressed' condition and 'water scarcity' condition arises when this is less than $1000 \mathrm{~m}^{3}$. So as shown in Fig.11, already water-stressed country India is very close to becoming water scare within few decades.

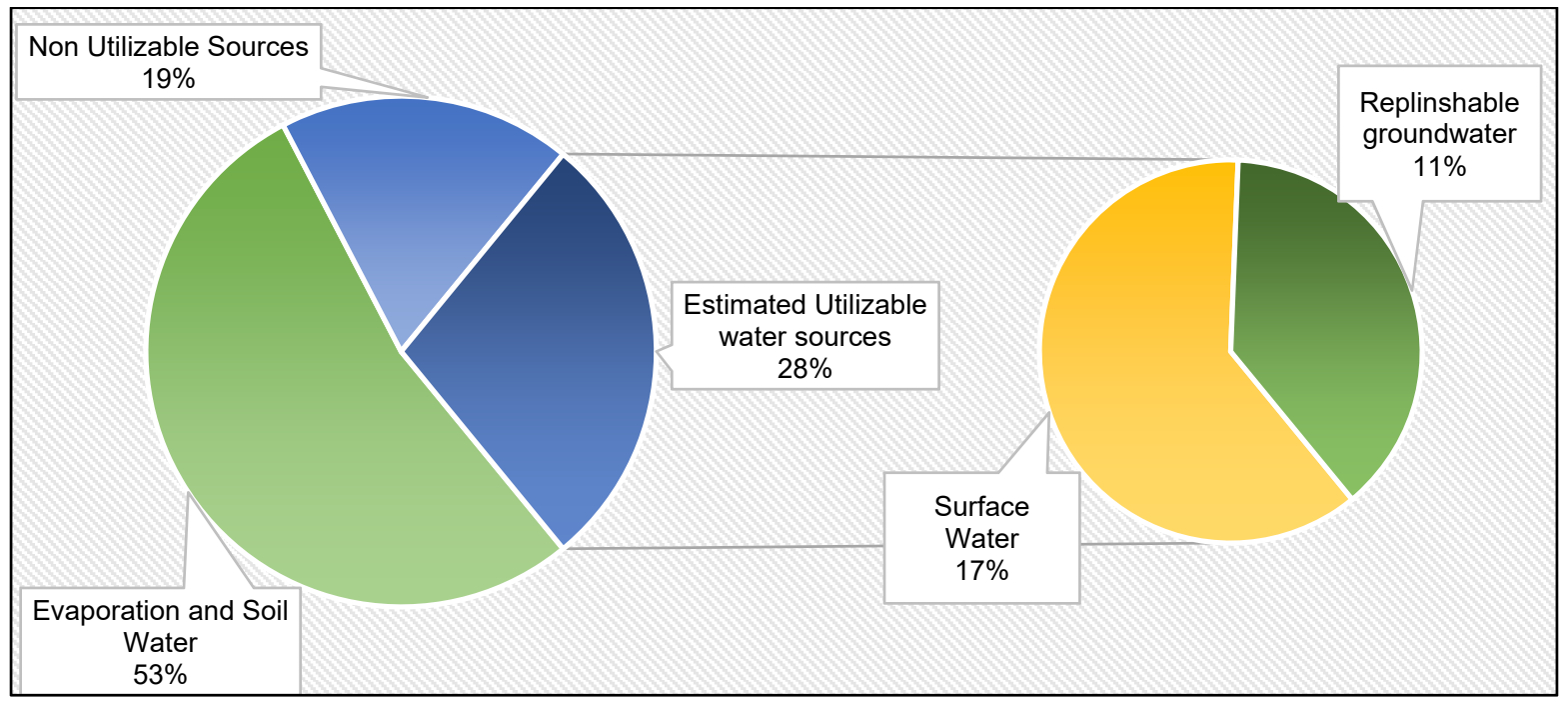

Fig.10: Detailed representation of water availability in India.

India, as the seventh largest country by geographical area, is the second most populated country in the world. According to the latest census estimation, the total population was figured to be 1299 million in 2016 against a population count of 359 million people in 1950. The trading economical global macro models and analysis has forecasted a population growth of about 1340 million in 2020. Growing population indicates a growing water demand along with more water scare condition. The water demand variation in India is given below in Fig. 12. By 2050, a major portion of available water will be used for energy generation in many industries. As $55 \%$ of water resource in India comes from groundwater sources, inefficient exploitation of groundwater for irrigation will cause paucity of water in future. Pollution of many 
holy rivers has badly affected their water carrying capacity, thereby decreasing the per capita water availability. So in a nutshell, the rapid growth of population in India has increased the burden on available water resources, causing uneven distribution of water both with respect to time and space, thereby leading more crucial water scarcity situation.

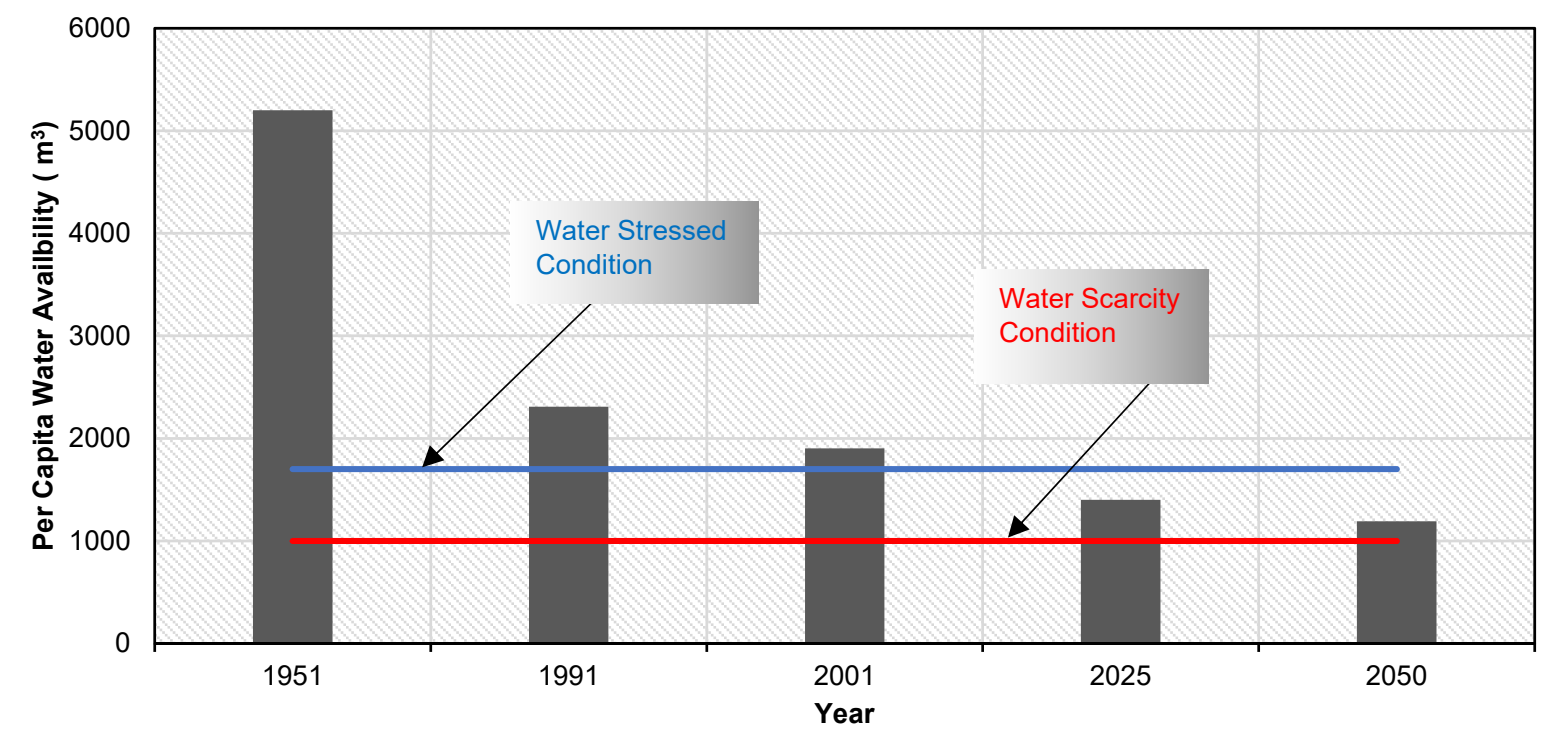

Fig.11: Per capita water availability in India.

In India, there are some governmental organizations which keep track of all these available water resources and their use, for the formulation of different policies and backing up data for planning and management programs. Out of them, here a brief glance at Central Water Commission (CWC) is given below, as the present study refers some of the hydrological data and facts provided by CWC.

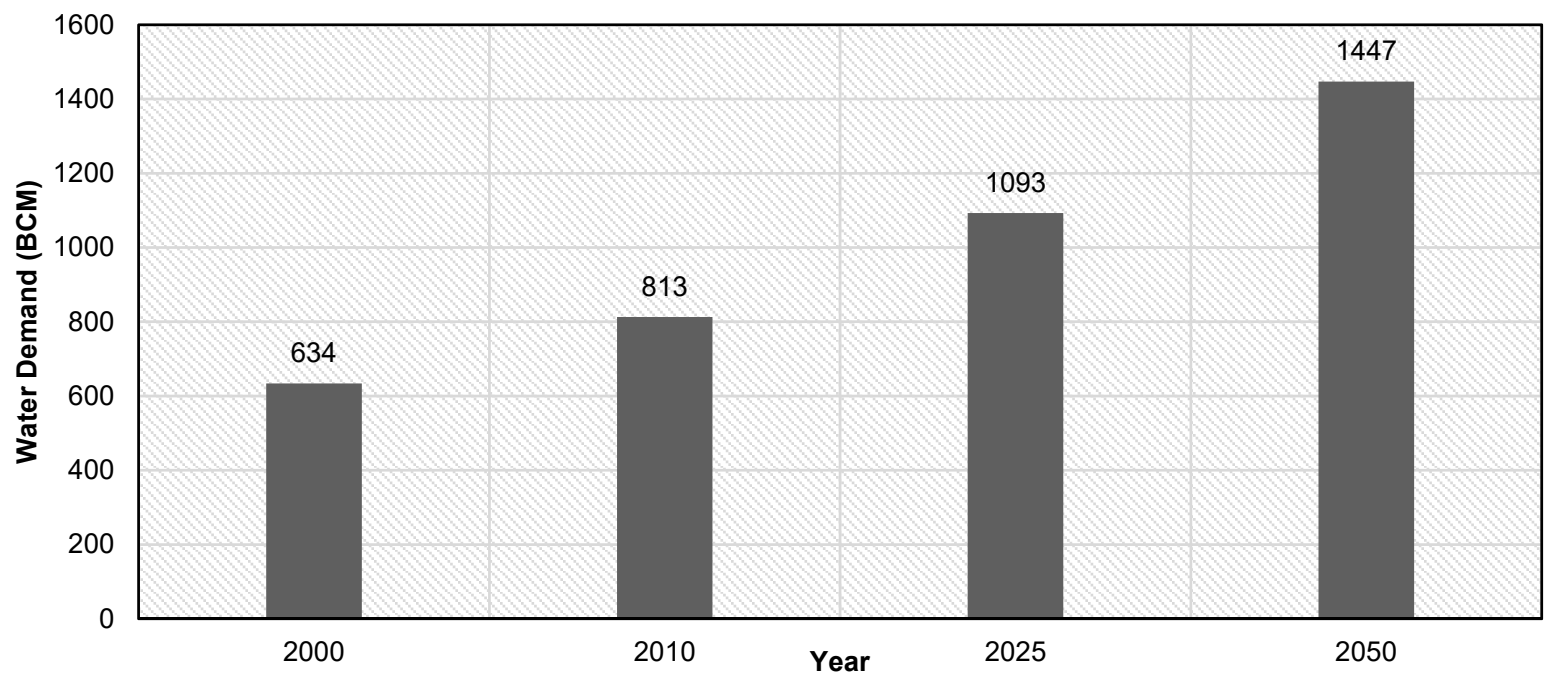

Fig.12: Growing water demand in India. 
Open access e-Journal

Earth Science India eISSN: $0974-8350$

Vol. 10 (IV), October, 2017, pp. 126 - 152

Earth Science India

http://www.earthscienceindia.info/

\section{Central Water Commission (CWC)}

Central Water Commission (CWC) is one of the leading institutes in India with an aim of integrated development and management of water resources by implementing state of art technology and involving all stakeholders. CWC has categorized all the Indian River basins into three classified river basins, such as Indus, Ganga, Brahmaputra and Barak and some minor rivers draining into Myanmar and Bangladesh. Hydrologic time series data for rest of the 12 non-classified river basins are given by CWC in form of Integrated Hydrological Data book (IHD). Out of 1091 hydrological observation sites of CWC, 465 operational sites are distributed over these non-classified river basins at which gauge, discharge, sediment and water quality data are being collected. The non-classified river basins according to CWC are; (i) Mahanadi, (ii) Subarnarekha, Burhabalang and Baitarani, (iii) Brahmani, (iv) Rushikulya, Vamsadhara, Sarada and Nagavali, (v) Godavari, (vi) Krishna, (vii) Cauvery, (viii) East flowing rivers between Mahanadi to Kanyakumari, (ix) West flowing rivers from Kanyakumari to Tapi, (x) Tapi, (xi) the Narmada, (xii) Mahi, Sabarmati and other West flowing rivers. Out of all these basins, Godavari, Krishna, and Mahanadi account for more than $50 \%$ of the total basin area. CWC has prepared a guideline for river basin planning in India namely 'Guidelines for Preparation of River Basin Master Plan'. Also, the 'Integrated Hydrological Data Book (Nonclassified river basins)' published by the Ministry of Water Resources, River Development and Ganga Rejuvenation in collaboration with CWC and ISO provides a great expose to available water resources in India and basin wise classification of each hydrological observations like gauge, discharge, sediment and water quality.

\section{Need for RBDPM in India}

As discussed above, India is moving towards water scarcity condition due to growing population and increasing water demand (i.e. demand expected to rise by $38 \%$ in the coming four decades). Pollution of river water and groundwater resources is also increasing at a faster rate due to municipal and industrial sewage disposal $(75 \%$ of total sewage is being discharged into the rivers and other water bodies), discharge of heavy metals like iron, fluoride etc. In the last few decades, variation in seasonal rainfall and climate change has affected many river basins in form of extreme events like flood and drought. Also, many political disputes have raised due to trans-boundary water issues, such as Mahanadi water dispute between Odisha and Chhattisgarh, Cauvery dispute etc. Keeping all these into consideration, the first National Water Policy (NWP) was formulated in 1987 for integrated water development and management. NWP (1987) summarizes the idea of River Basin Planning and Management as, "Water resource development and management will have to be planned for a hydrological unit such as drainage basin as a whole or a sub-basin, multi-sectorally, taking into account surface and groundwater for sustainable use incorporating quantity and quality aspects as well as environmental considerations". This policy was reviewed and updated in 2002 and again in 2012 also. NWP (2012) has the major focus on economic aspects of efficient water use and its conservation practices, instead of allocation priorities given in NWP (1987 and 2002).

All these water-related problems should be managed properly by applying holistic approaches at a basin level instead of any fragmented method which is mainly town-centric and confined within a particular state because one river basin is shared by multiple states. Therefore, the Indian government has started some remarkable sustainable river basin 
management programs with a holistic viewpoint, out of which the present article sheds light on the "Namami Gange" project started for cleaning the major holy river in India i.e. The Ganga River.

\section{NAMAMI GANGE: A HOLISTIC APPROACH FROM RIVER CLEANING TO RIVER REJUVENATION}

The Ganga River, which originates as Bhagirathi from the Gangotri glacier in the Himalayas travels a total length of $2525 \mathrm{~km}$ before falling into the Bay of Bengal at $150 \mathrm{~km}$ downstream of Kolkata. Eight principal tributaries of the river join the mainstream such as the Yamuna, the Ghaghra, the Gandak, the Burhi Gandak, the Ramganga, the Koshi, the Mahananda and the Sone. Nearly $43 \%$ of India's population is settled near the bank of this river and its tributaries. The Ganga drains into a very large catchment area of nearly 1086000 $\mathrm{km}^{2}$ extending over India, China, Nepal, and Bangladesh. In India the $79 \%$ of its entire basin spreads over eleven major states as shown in Fig.13, thereby draining into a huge basin with a spatial extent of $861404 \mathrm{~km}^{2}$, where there is extreme climate variability, change in land use and land cover pattern, and also social and cultural diversity. The basin falls within the geographical coordinates of $73^{\circ} 02^{\prime}$ to $89^{\circ} 05^{\prime} \mathrm{E}$ longitude and $21^{\circ} 06^{\prime}$ to $31^{\circ} 21^{\prime} \mathrm{N}$ latitudes, covering $26.2 \%$ of India's landmass. The major sources of water in the Ganga river are precipitation i.e. rainfall and snowfall in glacier region and the subsurface flow. The average rainfall in the basin is $110 \mathrm{~cm}$, out of which $80 \%$ occurs during monsoon season only. Because of the large areal extent and precipitation variability, flow characteristics or runoff in the river also fluctuates along its course, out of which only $50 \%$ of the surface flow is available for utilization. The total live storage capacity of the river basin is $56.326 \mathrm{BCM}$ while combining it with Brahmaputra and Barak and others, it is nearly $22.6 \%$ of the total live storage capacity of India. Groundwater storage by the basin is the largest in India i.e. $40 \%$ of the total estimated rechargeable groundwater resource of the country. $38 \%$ of total estimated utilizable water resources come from the Ganga basin, out of which surface water accounts for $48 \%$.

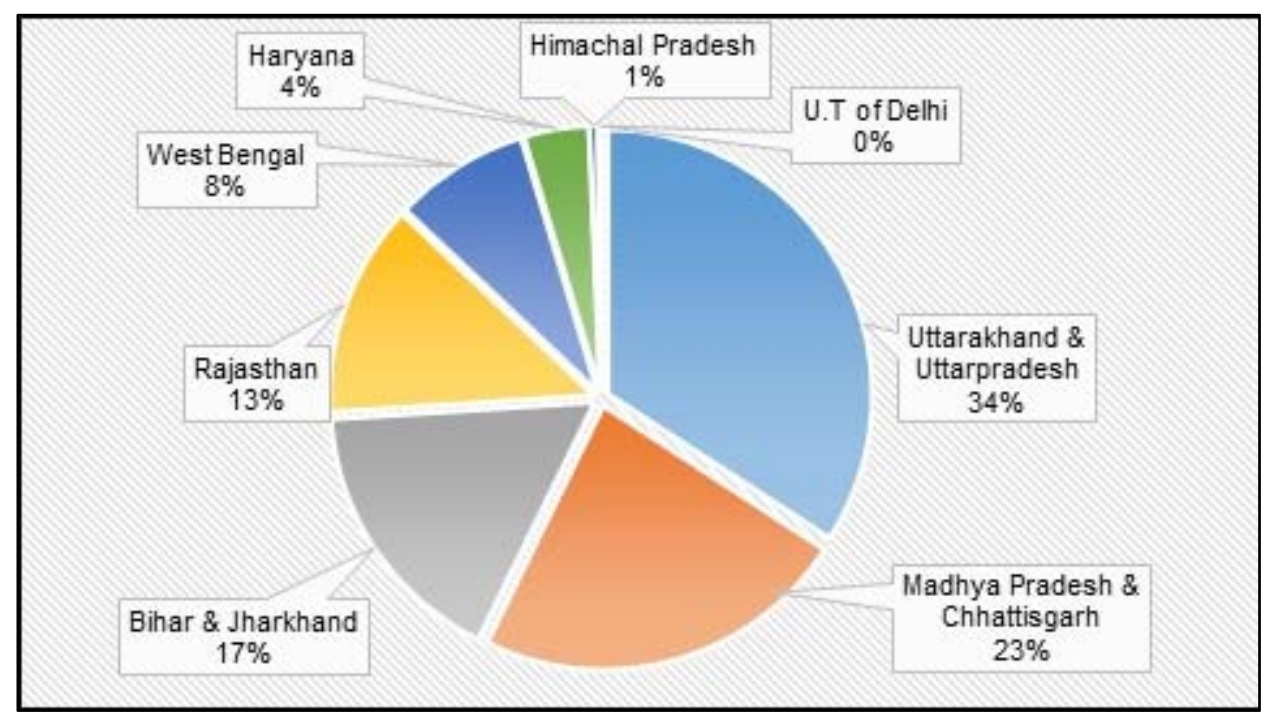

Fig.13: Statewise catchment area of river Ganga. 
Earth Science India

Open access e-Journal

Earth Science India eISSN: $0974-8350$

Vol. 10 (IV), October, 2017, pp. 126 - 152

http://www.earthscienceindia.info/

The Ganga basin has a condensed population with a density of 520 persons per square kilometer which is even more than the density of entire country i.e. 312 per square kilometer (according to Census 2001). During 2001 and 2011, the urban population within the basin has raised by $30 \%$ which is further likely to be increased in the coming decades. The rapid expansion of industrial and urban centers along the river course has increased the pollution load on its water resources due to heavy sewage disposal into the stream. The river is getting nearly 3000 MLD (Million Liters per Day) of sewage from various towns located along its bank, while till now the treatment capacity is only 1000 MLD. As a result of which, degradation of water quality is affecting human life and also many habitats on its bank.

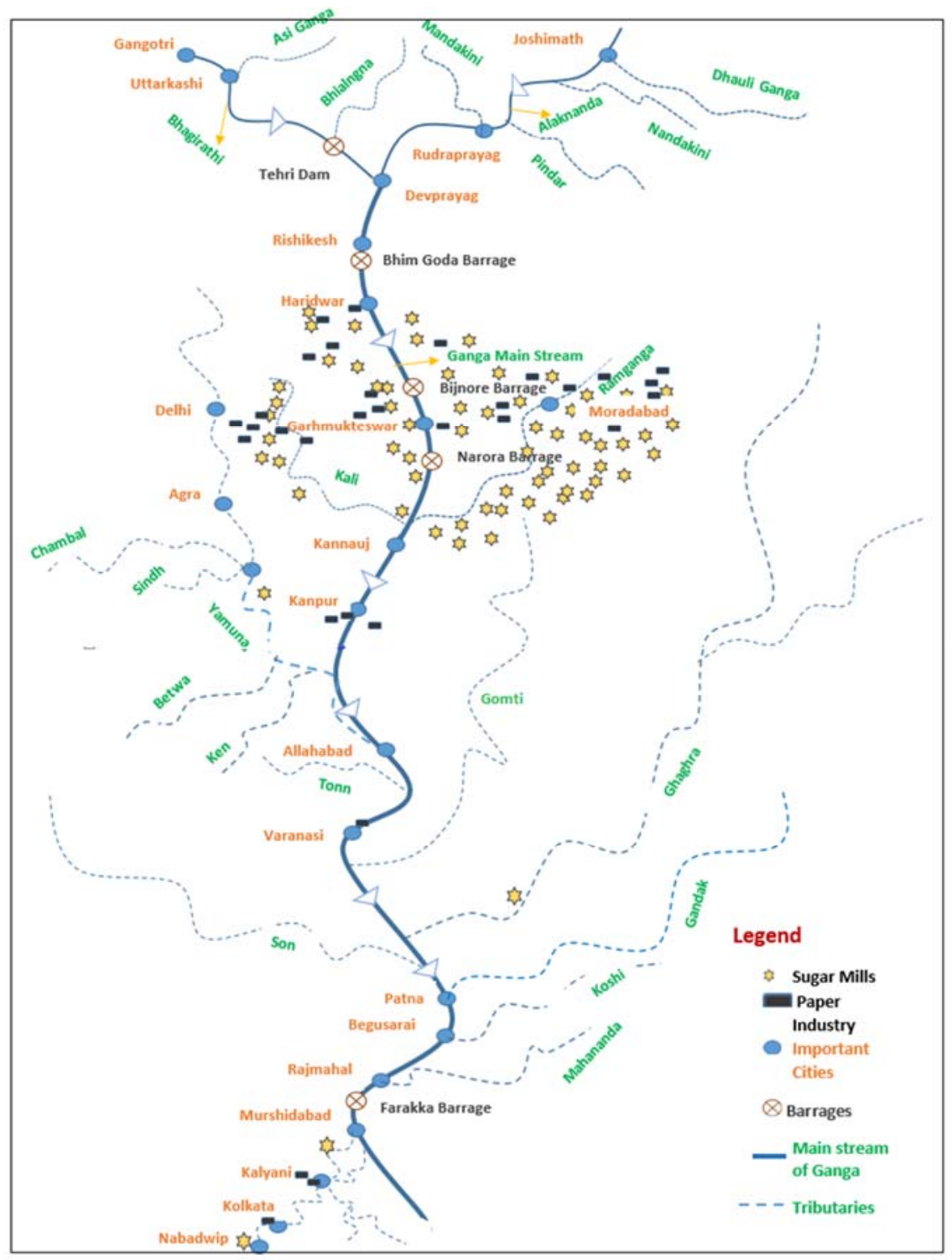

Fig. 14: River network of the Ganga. 
Here is a list comprising some major issues faced by the river Ganga.

- Rapid growth of population

- Alarming climate change effects on the upper stretch due to deforestation and glacier melt

- The Himalayan landslides

- Industrialization and urbanization along the river bank

- Large point and nonpoint pollution of river mainly in the middle stretch (Ramganga and Kali: major pollution center; fifth most polluted river in the world)

- Abstraction of huge quantity of water for industrialization and agriculture

- Occurrences of extreme events like flood and drought

- Trans-boundary problems with other countries in the lower stretch

So the above-mentioned challenges faced by the river Ganga has raised the need for a comprehensive river planning and management approach.

As this process of pollution is gradually evolving from a very old time, initially many actions were taken to clean the Ganga water but failed to give desired results. The 'Ganga Action Plan' (GAP) introduced in 1986 was the very first step in this direction, which had the main objective of cleaning the Ganga water by removing toxic materials, sewage, and other pollutants from the mainstream by means of diversion, interception or sewage treatment. The gap I covered 25 towns along the main stem of Ganga under 260 schemes. Later on GAP, I was extended to, four major tributaries of the Ganga River in its second phase during 1993 which covered 59 towns in five states. Then this plan was conducted at a national level through a 'National River Conservation Plan' (NRCP), which tried to focus on the lessons learned from GAP with the involvement of various state government organizations and concerned authorities. NRCP worked on 41 major rivers of the country, which included 5 Ganga basin rivers also. As the extent of pollution was still increasing, the Central Government of India established a 'National Ganga River Basin Authority' (NGRBA) in 2009, which declared Ganga as the 'National River' of India.

With all the experiences learned from these fragmented plans, a holistic basin level planning and management program for the river Ganga namely 'Namami Gange' was initiated by the Prime Minister of India in 2014 with a budget outlay of Rs.20,000 Crore for the socioeconomic benefits of the entire nation. Five major states of the basin such as Uttarakhand, Uttar Pradesh, Bihar, Jharkhand and West Bengal is considered in the Namami Gange project under the implanting body of NGRBA i.e. 'National Mission for Clean Ganga' (NMCG). All the tributaries and sub-tributaries of the Ganga is under this one plan 'Namami Gange', thereby making it an effective holistic approach. The sum and substance of this five-year plan (i.e. 2015-16 to 2019-20) is to decline the rate of pollution by proper sewage treatment, afforestation, and industrial monitoring; conservation of biodiversity; riverfront development along with surface cleaning; floodplain protection; increasing public awareness and development of gram panchayats situated on the bank of the river Ganga. Gradually active participation from various Central Ministries, state government authorities and water organizations of India and also MoU (Memorandum of Understanding) with many foreign countries have made this Ganga rejuvenation of an international interest. 
Earth Science India eISSN: $0974-8350$

Vol. 10 (IV), October, 2017, pp. 126 - 152

\section{INTER-STATE WATER DISPUTES IN INDIA}

In India most of the rivers flow across the boundaries of different states which has erupted many river water issues since independence. This type of issues, known as 'Inter State Water Disputes' mainly arise due to uneven distribution of water between the upstream and downstream states of a river. As the Indian economy mainly depends upon agriculture or irrigation water supply, sharing of river water judicially between various states has become a legal and constitutional concern for the development of the entire country. To take care of this unequal sharing of river water among the states, the central government forms tribunal consisting of Supreme Court judges as members to resolve all the issues and give the award. Many interstate water disputes have already raised in India starting from Krishna, Godavari and Narmada Dispute in the year of 1969, Cauvery 1990, Krishna again in 2004, Vansadhara in 2009 and the recent one is on the Mahanadi River. Out of all these cases, here in this article Krishna, Cauvery and Mahanadi disputesare presented briefly.

\section{Krishna Water Dispute}

The Krishna is the second biggest river in India originating at Mahabaleswar in Maharashtra and flowing through Maharashtra, Karnataka and the undivided Andhra Pradesh (nearly $1300 \mathrm{~km}$ ) before draining into the Bay of Bengal as shown in Fig.15. The river extends over these states forming a large catchment having an area about $258948 \mathrm{Sq}$. $\mathrm{km}$. The entire basin lying within the geographical coordinates of $73^{\circ} 17^{\prime}$ to $81^{\circ} 9^{\prime} \mathrm{E}$ longitude and $13^{0} 10^{\prime}$ to $19^{\circ} 22^{\prime} \mathrm{N}$ latitude, has its major portion covered by mainly agricultural lands and water bodies.

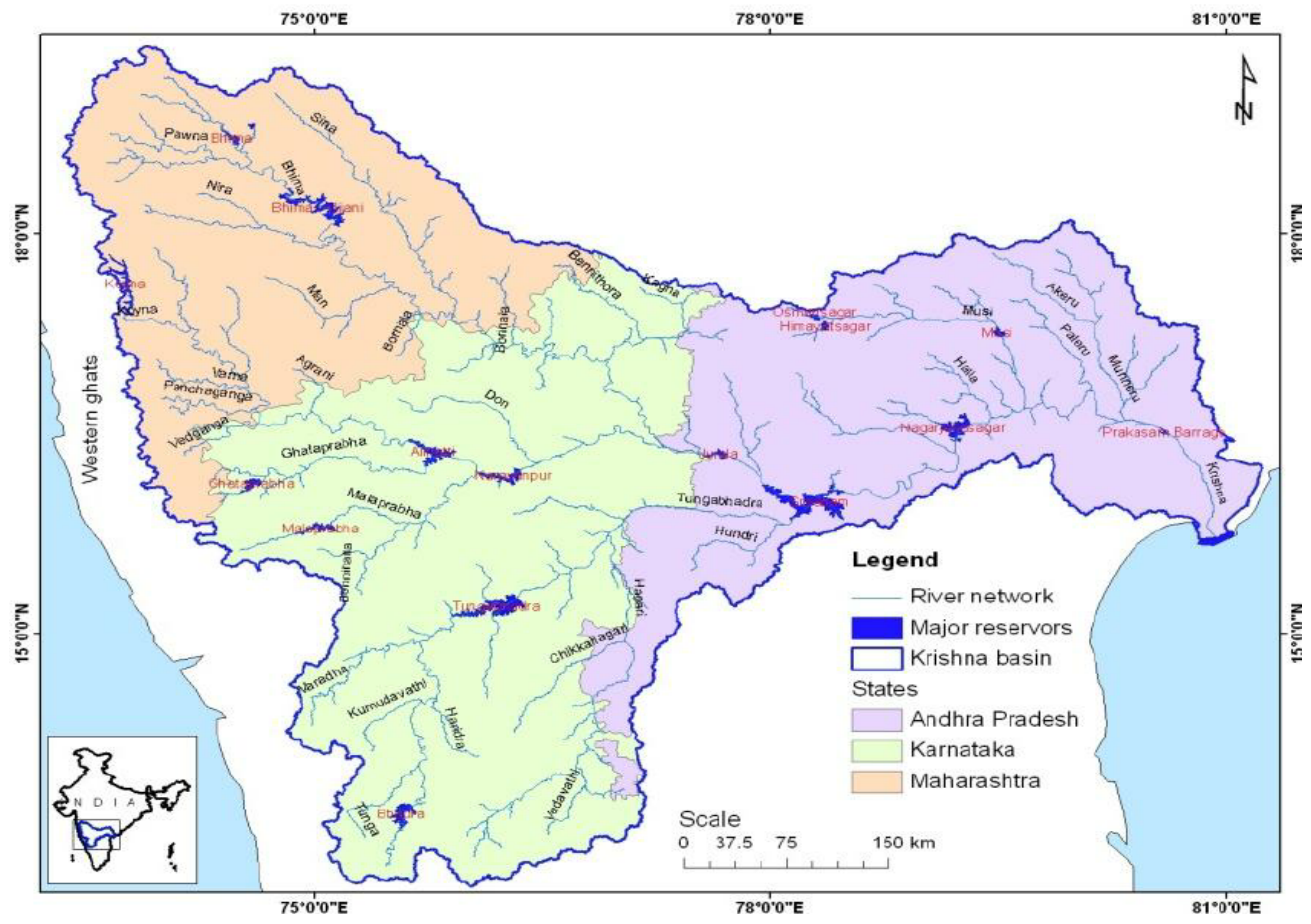

Fig.15: The Krishna River Basin extracted from SRTM 90m (Source: Gumma et al., 2011). 
The very first dispute on the Krishna river was started in 1969, for which Krishna Water Dispute Tribunal- I (KWDT I, known as 'Bachawat Tribunal') was formed in April 1969 under the Indian constitution, whose reports with decisions were delivered in 1973 and further in 1976 also. This conflict raised when Mysore (presently Karnataka) claimed on equal distribution of the Krishna water and also opposed construction of some hydro projects in Andhra Pradesh and westward diversion of more water by Maharashtra. The tribunal figured out seven major issues on this and after analyzing thoroughly it gave the final award with an exact share of three states as 560 TMC by Maharashtra, 700 TMC by Karnataka and 800 TMC by Andhra Pradesh. When all the three states failed to provide the review of this award even after three years of its announcement (i.e. in 2000), the second committee KWDT II came into action from June 2007. KWDT II gave its award in 2010 when the available water was distributed based on $65 \%$ dependability, considering flow data of last 47 years. According to this award water allocated to Maharashtra, Karnataka and Andhra Pradesh were 666, 911 and 1001 TMC respectively. A hydrologic time series (for a period of 117 years) of subbasins of the Krishna Basin of Andhra Pradesh in order to help KWDT II on its award. This award has a validity up to May 2050 and can be modified if required in future. The final verdict was given in 2013 when only the Andhra Pradesh share was increased by 4 TMC by reducing the share of Karnataka. Later after the reorganization of Andhra Pradesh, it was decided that the share of the undivided Andhra Pradesh will be effectively allocated between Telangana and Andhra Pradesh. However, this matter is still not resolved completely as some of the irrigation experts are raising the question of injustice given to Telangana regarding the distribution of the Krishna water.

\section{Cauvery Water Dispute}

The Cauvery River, also known as Dakshin Ganga is one of the major rivers in India originates at Talakaveri in Coorg District of Karnataka and travels a length of nearly $800 \mathrm{~km}$ before draining into the Bay of Bengal. It has a large basin area of $81155 \mathrm{Sq}$. $\mathrm{km}$ extending over Karnataka, Tamil Nadu, Kerala and Union Territory of Pondicherry. This lies within the geographical coordinates of $75^{\circ} 27^{\prime}$ to $79^{\circ} 54^{\prime} \mathrm{E}$ longitudes and $10^{\circ} 9^{\prime}$ to $13^{\circ} 30^{\prime} \mathrm{N}$ latitudes with the major portion covered by agricultural lands and water bodies.

The equitable sharing of the Cauvery water between Karnataka and Tamil Nadu has been a source of contention for many decades (initially started in 1892), whereas the other two states also joined the conflict at a later stage. Earlier the Cauvery water was regulated by the agreements of 1892 and 1924 between Mysore and the Madras Presidency. According to these agreements, the share of Cauvery water by Tamil Nadu and Pondicherry, Karnataka, and Kerala was $75 \%, 23 \%$, and $2 \%$ respectively. The 1924 agreement came into the light because of the objection filed by Madras on the construction of Krishnaraj Sagar dam by Mysore, which was later settled by allowing Madras to build the Mettur Dam. Again the reorganization of states in 1956 and also the occurrence of natural disasters like floods and drought in the basin area raised the conflicts between them. Gradually Tamil Nadu wanted more diversion of water with the development of agricultural pattern, while Karnataka wanted to control most of the water flowing through it. So the major objection of Tamil Nadu was in the construction of many water storage structures in the upstream region by Karnataka, which dropped the available water level on the downstream side. To resolve all the issues, a Cauvery Fact Finding Committee (CFFC) was established, whose final draft in 1976, which was later 
Open access e-Journal

Earth Science India eISSN: $0974-8350$

Vol. 10 (IV), October, 2017, pp. 126 - 152

http://www.earthscienceindia.info/

rejected by the Tamil Nadu government. Finally, the Supreme Court decided to form a tribunal to analyze the matter judicially and properly allocate water among all the four states. An interim award was given by this tribunal in 1991, which asked Karnataka to ensure a flow of 205 TMC to Tamil Nadu in every water year. However, this turned into a social violence in many parts of the Karnataka, mainly centered in Bengaluru. So the Karnataka government rejected the tribunal award. In 1995, due to very less monsoon rainfall, CWDT asked Karnataka to release 11 TMC to Tamil Nadu, which was again rejected by the Karnataka government. The final award of this dispute was given in 2007 by three members of this CWDT, which allocated the river water share as 419 TMC by Tamil Nadu, 270 TMC by Karnataka, 30 TMC by Kerala and 7 TMC by Pondicherry. To regulate this diversion of water, a monitoring authority was formed. However, due to growing demand of water in Karnataka, it again started objection to its share portion. In 2013 the center notified the final award of CWDT. Again this issue was raised in Karnataka due to the order of the Supreme Court to release more water to Tamil Nadu in 2016. Recently in July 2017, Tamil Nadu government has again questioned the shortfall of nearly 5.966 TMC of water by Karnataka.

The changing effect of climate within the basin, occurrence of natural disasters, rapidly growing urbanization and industrialization needs have made this Cauvery water dispute a local manifestation of planetary conflicts, which requires a scientific, holistic management of the river water at the basin level.

\section{Mahanadi Dispute}

The Mahanadi is one of the major river in east-central India with origin lying near Pharsiya village of Raipur, Chhattisgarh and having a total length of $851 \mathrm{~km}$. A major portion of the river flows in the state of Chhattisgarh, Odisha and some portion in Jharkhand and it finally falls into the Bay of Bengal through a number of channels near Paradeep at the False point, Jagatsinghpur, Odisha. It has 14 major tributaries, out of which 12 drains into the main channel upstream of Hirakud reservoir and 2 downstream of it. The Mahanadi basin extends primarily over two states i.e. Chhattisgarh and Odisha, having a total drainage area of $141589 \mathrm{Sq} . \mathrm{km}$ with mean annual river flow of 59155 million cubic meters (MCM). The entire river basin lies within the geographical coordinates of $19^{\circ} 8^{\prime}$ to $23^{\circ} 32^{\prime} \mathrm{N}$ latitude and $80^{\circ} 28^{\prime}$ to $86^{\circ} 43^{\prime} \mathrm{E}$ longitude. A moderate spatial variation in rainfall occurs in the basin such as annual rainfall varying from 1143 to $2032 \mathrm{~mm}$ with an average of $1438.1 \mathrm{~mm}$. The basin experiences more than $90 \%$ of total rainfall during monsoon season i.e. from June to October. Because of its large size, a lot of geographical and climatic change is observed over the entire watershed.

The total annual average flow in Mahanadi is $66.9 \mathrm{BCM}$; where $13.006 \mathrm{BCM}$ has stored in different completed projects and $1.4613 \mathrm{BCM}$ is under construction. To account for all the hydrological changes, CWC has placed 46 observational sites in Mahanadi Basin, out of which one is for rainfall measurement, discharge is observed at 21 sites, sediment at 16 sites. Manendragarh site located in Chhattisgarh, has the minimum catchment area with the highest peak water level data (in 1990), as per CWC hydrological data book. Tikarapara is the terminal site having a drainage area of $124450 \mathrm{~km}^{2}$ which leads to an average annual runoff of 47815 MCM (1972-73 to 2013-14). The Mahanadi river basin is expected to be the worst affected 
river basin in India in terms of the increased intensity of floods due to climate change, where the last decade has already seen five high floods occurring in the basin (Jena et al., 2014).

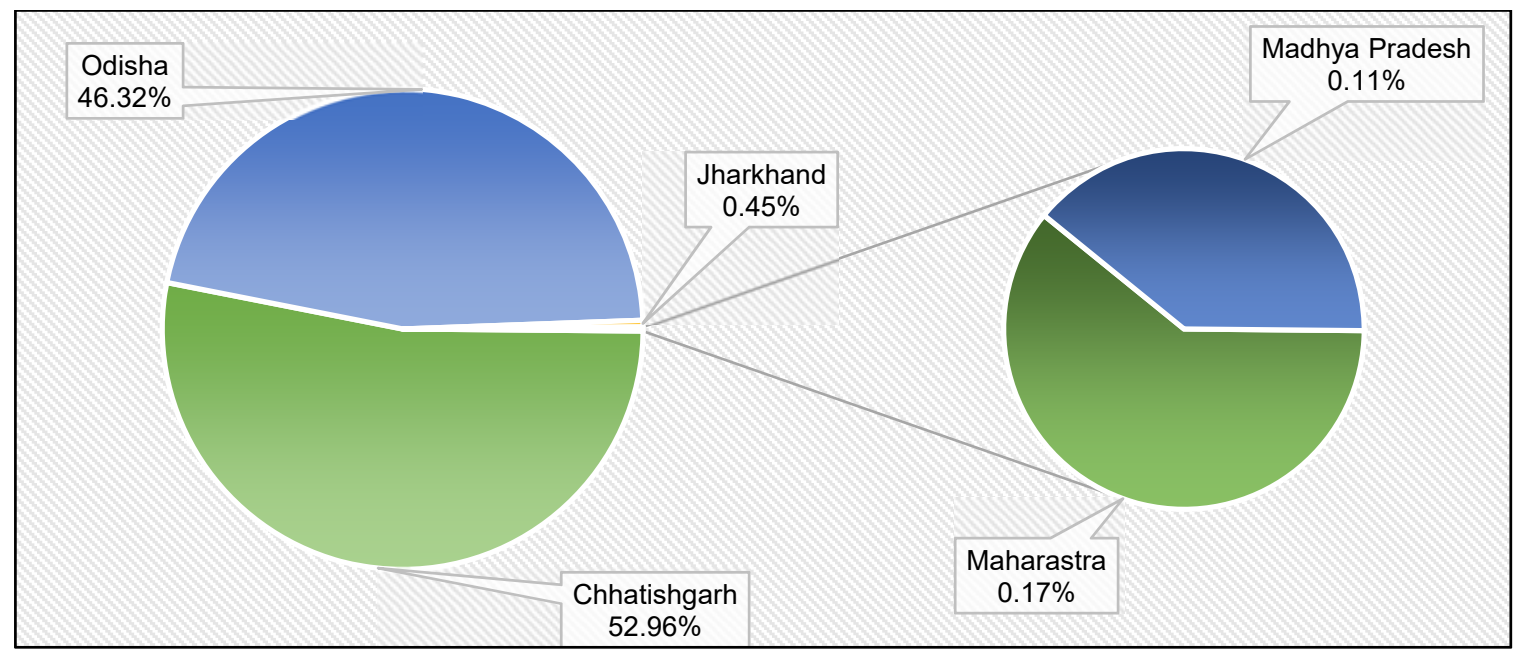

Fig.16: State-wise portion of Mahanadi Basin.

Currently, a major dispute has raised regarding the distribution of the Mahanadi river water between two states i.e. Odisha and Chhattisgarh. As reported by Odisha government officials, in the last few years inflow to the Hirakud reservoir during the non-monsoon season has decreased significantly due to the construction of several weirs and barrages by Chhattisgarh government. This reduction of inflow is significant since November 2016 due to the operation of six barrages by the neighboring state. As reported by Odisha Water Resource Department, the reduction in the flow of water in April and May 2017 was $68.09 \%$ and $75.9 \%$ respectively as compared to 2011. The Government of Odisha has reported that Chhattisgarh has started many projects on the upstream of Hirakud reservoir, which will have a severe effect on the areas lying downstream of the reservoir during lean period i.e. non-monsoon season.

A schematic diagram of the Mahanadi River network along with the location of GD or GDQ or GDSQ sites of CWC on the upstream and downstream of Hirakud reservoir is given below. CWC has placed total 46 observation sites in Mahanadi basin which includes 4 GD, 1 GDQ, and 16 GDSQ sites (G- Gauge, D- Discharge, S- Sediment, and Q-Water Quality). Here inFig.17, the 21 sites having both gauge and discharge readings are considered in the analysis. The middle reach of Mahanadi basin between Hirakud reservoir and Mundali weir mainly encompasses agricultural fields (nearly $60 \%$ of the total geographical area of the middle region). During non-monsoon season, this area mainly depends upon the supply from three canals carrying water from Hirakud reservoir. So decrease in inflow to the reservoir during the lean period will severely affect the downstream portion and ultimately the social and economic strength of Odisha. So this needs a sustainable holistic planning of the entire basin, to focus on some of the major aspects of water supply for irrigation and power generation, construction of structures on the upstream of Hirakud reservoir and flood control. 
Open access e-Journal

Earth Science India eISSN: $0974-8350$

Vol. 10 (IV), October, 2017, pp. 126 - 152

Earth Science India

http://www.earthscienceindia.info/

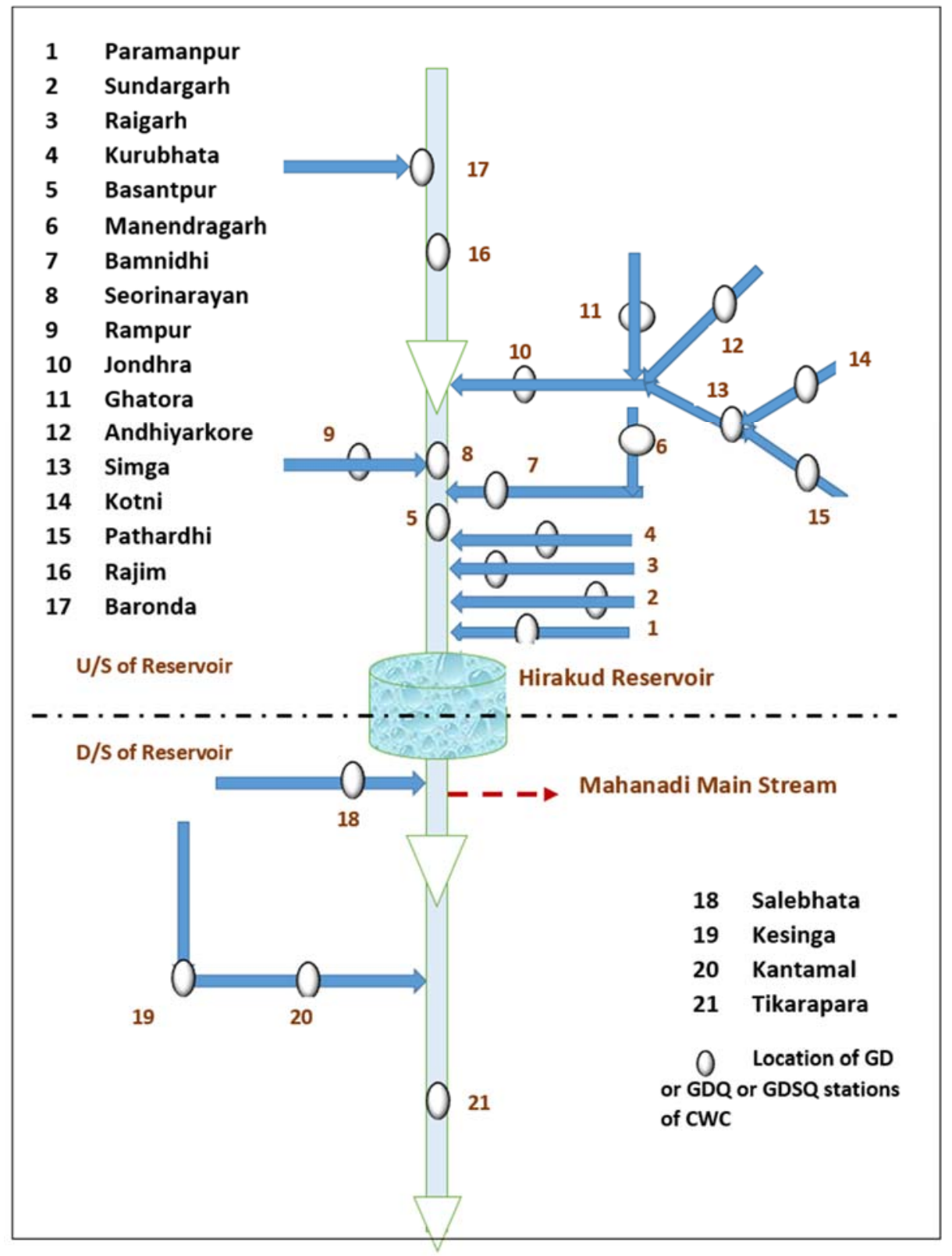

Fig.17: River Network of the Mahanadi showing location of GD or GDQ or GDSQ gauging sites established by CWC.

Basantpur, one of the CWC site lying on the upstream of Hirakud reservoir, is located in Chhattisgarh with a total catchment area of $57780 \mathrm{~km}^{2}$. The average non-monsoon flow observed at Basantpur for a period of 10 years (i.e. from 2004-2005 to 2013-2014) is taken from Integrated Hydrological Data-book (Integrated Hydrological Data Book, 2017) and plotted below as shown in Fig. 18(a). 


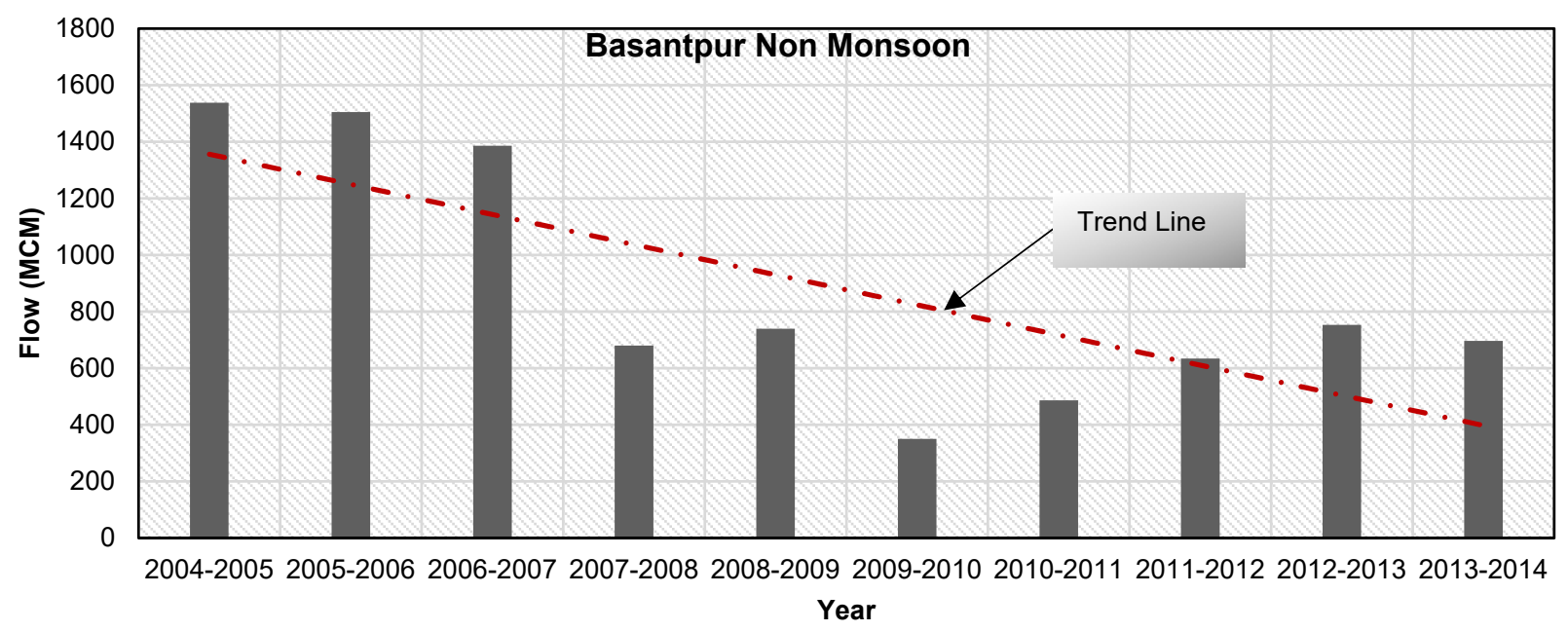

Fig. 18: Variation in Non-monsoon flow at Basantpur.

Trend analysis test performed on this series showed Kendall's tau value of -0.422 , which signifies the presence of a negative trend. From the plot, it can be interpreted that the average flow at Basantpur site during the non-monsoon period is decreasing since last few years. A similar analysis is performed for another site Rajim located on the main river upstream of the Hirakud reservoir and plotted inFig. 19Kendall's tau (T) value for the site is found to be -0.467 , which shows the average non-monsoon discharge at Rajim has a decreasing trend over time.

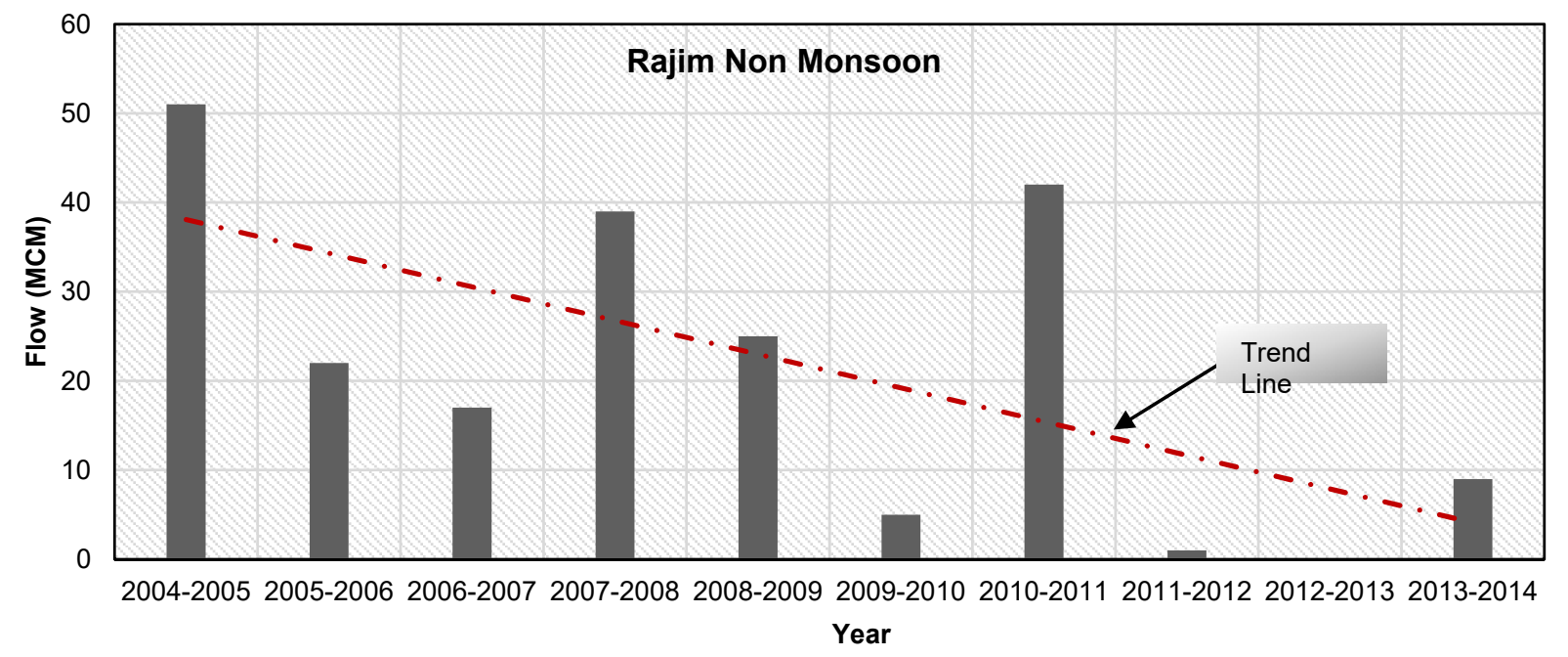

Fig. 19: Variation in Non-monsoon flow at Rajim.

So from the above analysis, it is obvious that the average discharge at the upstream side of Hirakud reservoir is gradually reducing during the non-monsoon season, which in a long run will definitely affect the downstream region situated in Odisha. As reported in some articles, this decrease in inflow to Hirakud reservoir is mainly due to the construction of many hydrological structures like barrage, dam etc. on the upstream side in Chhattisgarh. Also, the heavy industrialization and deforestation on the upstream side of Hirakud have raised the 
siltation problem, thereby reducing the retention capacity of the dam. According to a news article published in 'The Telegraph', the water holding capacity of the dam has been reduced by $17 \%$ of its live storage capacity by the year 2006 and further study is going on by National Remote Sensing Authority. The water holding capacity has been reduced to 3.8 million acrefeet from 4.72 million acre-feet. This gradual drop in the capacity will have a negative impact on power generation and irrigation on the downstream side. Also, the reservoir couldn't hold the heavy inflow during monsoon season, which gets directly discharged to the sea and thereby causing severe flood damage in the deltaic region.

Perhaps, following might be some solutions to these conflicts, but each has its own limitation and disadvantage.

- Construction of some hydraulic structures on the downstream of Hirakud reservoir; however, it may affect the social and environmental life due to deforestation, resettlement, and submergence of some localities

- Desiltation of Hirakud reservoir; but it may not be that much economical. Failure of de-siltation project for Damodar valley is a lesson

- Industrialization and deforestation on the upstream side can be controlled keeping in view the economy of the states involved

- Applying some de-siltation mechanism in the canals or barrages draining water to the Hirakud dam

- Inter-basin transfer of water, which itself is again a very complex process

There lie some serious problems in the Mahanadi River basin due to all these water disputes between Odisha and Chhattisgarh, which may become worse in near future due to the adverse effect of rapidly changing climate. So all these require a sustainable river basin planning approach with the active participation of both the states along with other concerned governmental bodies for the social and economic welfare of the nation as a whole.

\section{SUMMARY}

The concept of river basin planning and management has seen various stages of evolution for many decades, but still, it is a major topic of concern all over the world. The rapidly growing population along with sudden climate change has made this a political and social issue in many countries. With the increase in the level of uncertainties and complexities involved in the system, river basin planning requires a holistic approach for the socio-economic benefit of any country. The rivers in India play a vital role in its economy as it is an agricultural dominated country. However, the exponentially increasing urbanization and industrialization needs, the occurrence of flood and drought, grappling with interstate water disputes in many river basins have become a source of political and social issues nowadays. So being a waterstressed country, India needs to focus on effective sustainable planning and management of river basin to properly utilize the available water resources. Holistic modeling can be a simple approach in this regard, as it combines both ecological and economic aspects, however, it comes with its own difficulties of data handling, dealing uncertainties, calibration, and largescale applications. Keeping all this in view, sustainable river basin planning in India needs a special attention with the active participation of governmental organizations and public support. 
Sustainable River Basin Management Planning: A Holistic Approach: Swetapadma and Ojha

\section{REFERENCES}

Barrow, C. J. (1998) River basin development planning and management: A critical review. World Developemnt, v. 26(1), pp. 171-186.

Basu, B. and Srinivas, V. V (2013) Regional flood frequency analysis using Entropy-Based Clustering Approach. J. Hydrologic Engg., v. 21(8), pp. 1-12. doi: 10.1061/(ASCE)HE.1943-5584.0001351.

Booker, J. F., Michelsen, A. M. and Ward, F. A. (2005) Economic impact of alternative policy responses to prolonged and severe drought in the Rio Grande Basin.Water Resource Research, v. 41, pp. 1-16. doi: 10.1029/2004WR003486.

Braat, L. C. and Lierop, W.F.J. (1987) Integrated economic-ecological modelling, In: L.C. Braat, and W.E.J. Liero, (eds.), Integrated Economic Ecological Modeling,North Holland. Studies in Regional Science and Urban Economics, v. 16, pp. 49-67.

Cai, X., Mckinney, D. C. and Lasdon, L. S. (2002) A framework for sustainability analysis in water resources management and application to the Syr Darya Basin. Water Resource Research, v. 38(6), pp. 21-1-21-14.

Cai, X., Mckinney, D. C. and Lasdon, L. S. (2003) Integrated hydrologic-agronomic-economic model for river basin management. Journal of Water Resources Planning and Management, v. 129(1), pp. 4-17.

Cai, X., Ringler, C. and Rosegrant M. W. (2006) Modeling water resources management at the basin level: Methodology and application to the Maipo River Basin. Research Report, 149. International Flood Policy Research Institute, Washington, DC.

Chitale, M.A. (1992) Development of India's river basins. International Journal of Water Resources Development, v. 8(1), pp 30-44.

Farolfi, S., Müller, J. and Bonté, B. (2010) An iterative construction of multi-agent models to represent water supply and demand dynamics at the catchment level. Environmental Modelling \& Software, v. 25(10), pp. 1130-1148. doi: 10.1016/j.envsoft.2010.03.018.

Girard, C., Rinaudo, J., Pulido-Velazquez, M. and Caballero, Y. (2015) An interdisciplinary modelling framework for selecting adaptation measures at the river basin scale in a global change scenario. Environmental Modelling and Software, v. 69, pp. 42-54. doi: 10.1016/j.envsoft.2015.02.023.

Gumma, M. K., Thenkabail, P. and Nelson, A. (2011) Mapping irrigated areas using MODIS 250 meter time-series data: a study on Krishna River Baisn (India). Water, v. 3, pp. 113-131. doi: 10.3390/w3010113.

Guowei, L.I.U. (2001) Hydrology in ancient time in China. Paper presented to the International Symposium $\mathrm{OH}_{2}$ ' Origins and Histroy of Hydrology', Dijon, May 9-11, 2001.

Ministry of Water Resources, River Development \& Ganga Rejuvenation (2017) Integrated Hydrological Data Book (Non-Classified River Basins), New Delhi, India.

Jena, P. P., Chatterjee, C., Pradhan G. and Mishra, A. (2014) Are recent frequent high floods in Mahanadi basin in eastern India due to increase in extreme rainfalls? Journal of Hydrology, $v$. 517, pp. 847-862. doi: 10.1016/j.jhydrol.2014.06.021.

Jenkins, M. W., Lund, J. R., Howitt, R. E., Draper, A. J., Msangi, S. M., Tanaka, S. K., Ritzema R. S. and Marques, G. F. (2004) Optimization of California's water upply system : Results and insights. Journal of Water Resources Planning and Management, v.130(4), pp. 271-280.

Kotir, J. H., Smith, C., Brown, G., Marshall, N. and Johnstone, R. (2016) Science of the total environment: A system dynamics simulation model for sustainable water resources management and agricultural development in the Volta River Basin, Ghana. Science of the Total Environment, v. 573, pp. 444-457. doi: 10.1016/j.scitotenv.2016.08.081.

Kotir, J. H., Brown, G., Marshall, N. and Johnstone, R. (2017) Systemic feedback modelling for sustainable water resources management and agricultural development: An application of participatory modelling approach in the Volta River Basin. Environmental Modelling and Software. Elsevier Ltd, v. 88, pp. 106-118. doi: 10.1016/j.envsoft.2016.11.015.

Levin, S., Xepapadeas, T., Crepin, A., Norberg, J., Zeeuw, A., Folke, C., Hughes, T., Arrow, K., Barrett, S., Daily, G., Ehrlich, P., Kautsky, N., Maler, K., Polasky, S., Troell, M., Vincent, J. R. and 
Walker, B. (2013) Social - ecological systems as complex adaptive systems : modeling and policy implications. Enviroment and Development Economics, v.18(2), pp 111-132. doi: 10.1017/S1355770X12000460.

Mccarl, B. A., Dillon, C. R., Keplinger, K. O. and Williams, R. L. (1999) Limiting pumping from the Edwards Aquifer: An economic investigation of proposals, water markets, and spring flow guarantees. Water Resource Research, v. 35(4), pp. 1257-1268.

Mirchi, A., Madani, K., Watkins, D. and Ahmad, S. (2012) Synthesis of system dynamics tools for holistic conceptualization of water resources problems. Water Resource Management, v. 26(9), pp. 2421-2442. doi: 10.1007/s11269-012-0024-2.

Molle, F. (2009) Geoforum river-basin planning and management: The social life of a concept. Geoforum, Elsevier Ltd, v. 40(3), pp. 484-494. doi: 10.1016/j.geoforum.2009.03.004.

Pahl-wostl, C., Arthington, A., Bogardi, J., Bunn, S. E., Hoff, H., Lebel, L., Nikitina, E., Palmer, M., Poff, L. N., Richards, K., Schluter, M., Schulze, R., St-Hilaire, A., Tharme, R., Tockner, K. and Tsegai, D. (2013) Environmental flows and water governance: managing sustainable water uses. Current Opinion in Enviromental Sustainability, v. 5(3-4), pp. 341-351.

Schoups, G., Addams, C. L., Minjares, J. L. and Gorelick, S. M. (2006) Sustainable conjunctive water management in irrigated agriculture: Model formulation and application to the Yaqui Valley, Mexico. Water Resource Research, v. 42 (10), W10417, pp. 1-19. doi: 10.1029/2006WR004922. 